\title{
Lanthanoid-free perovskite oxide catalyst for dehydrogenation of ethylbenzene working with redox mechanism
}

\section{Ryo Watanabe ${ }^{1}$, Maiko Ikushima $^{2}$, Kei Mukawa ${ }^{2}$, Fumitaka Sumomozawa $^{2}$, Shuhei Ogo ${ }^{2}$ and Yasushi Sekine ${ }^{2 *}$}

${ }^{1}$ Department of Materials Science and Chemical Engineering, Faculty of Engineering, Shizuoka University, Hamamatsu, Japan

${ }^{2}$ Department of Applied Chemistry, School of Science and Engineering, Waseda University, Tokyo, Japan

\section{Edited by:}

Viswanathan Balasubramanian, Indian Institute of Technology,

Madras, India

Reviewed by:

Andrzej Kolodziej, Institute of Chemical Engineering of the Polish Academy of Sciences, Poland Zheng Ren, University of

Connecticut, USA

Krishnamurthy K. Ramaswamy

Indian Institute of Technology,

Madras, India

*Correspondence:

Yasushi Sekine, Department of Applied Chemistry, School of

Science and Engineering, Waseda University, 65-301A, 3-4-1, Okubo, Shinjuku, Tokyo 1698555, Japan

e-mail:ysekine@waseda.jp
For the development of highly active and robust catalysts for dehydrogenation of ethylbenzene $(\mathrm{EBDH})$ to produce styrene; an important monomer for polystyrene production, perovskite-type oxides were applied to the reaction. Controlling the mobility of lattice oxygen by changing the structure of $\mathrm{Ba}_{1-x} \mathrm{Sr}_{x} \mathrm{Fe}_{y} \mathrm{Mn}_{1-y} \mathrm{O}_{3-\delta}(0 \leq x \leq 1,0.2 \leq$ $y \leq 0.8$ ), perovskite catalyst showed higher activity and stability on EBDH. The optimized $\mathrm{Ba} / \mathrm{Sr}$ and $\mathrm{Fe} / \mathrm{Mn}$ molar ratios were $0.4 / 0.6$ and 0.6/0.4, respectively. Comparison of the dehydrogenation activity of $\mathrm{Ba}_{0.4} \mathrm{Sr}_{0.6} \mathrm{Fe}_{0.6} \mathrm{Mn}_{0.4} \mathrm{O}_{3-\delta}$ catalyst with that of an industrial potassium promoted iron (Fe-K) catalyst revealed that the $\mathrm{Ba}_{0.4} \mathrm{Sr}_{0.6} \mathrm{Fe}_{0.6} \mathrm{Mn}_{0.4} \mathrm{O}_{3-\delta}$ catalyst showed higher initial activity than the industrial Fe-K oxide catalyst. Additionally, the $\mathrm{Ba}_{0.4} \mathrm{Sr}_{0.6} \mathrm{Fe}_{0.6} \mathrm{Mn}_{0.4} \mathrm{O}_{3-\delta}$ catalyst showed high activity and stability under severe conditions, even at temperatures as low as $783 \mathrm{~K}$, or at the low steam/EB ratio of 2, while, the $\mathrm{Fe}-\mathrm{K}$ catalyst showed low activity in such conditions. Comparing reduction profiles of the $\mathrm{Ba}_{0.4} \mathrm{Sr}_{0.6} \mathrm{Fe}_{0.6} \mathrm{Mn}_{0.4} \mathrm{O}_{3-\delta}$ and the $\mathrm{Fe}-\mathrm{K}$ catalysts in a $\mathrm{H}_{2} \mathrm{O} / \mathrm{H}_{2}$ atmosphere, reduction was suppressed by the presence of $\mathrm{H}_{2} \mathrm{O}$ over the $\mathrm{Ba}_{0.4} \mathrm{Sr}_{0.6} \mathrm{Fe}_{0.6} \mathrm{Mn}_{0.4} \mathrm{O}_{3-\delta}$ catalyst while the Fe-K catalyst was reduced. In other words, $\mathrm{Ba}_{0.4} \mathrm{Sr}_{0.6} \mathrm{Fe}_{0.6} \mathrm{Mn}_{0.4} \mathrm{O}_{3-\delta}$ catalyst had higher potential for activating the steam than the Fe-K catalyst. The lattice oxygen in perovskite-structure was consumed by $\mathrm{H}_{2}$, subsequently the consumed lattice oxygen was regenerated by $\mathrm{H}_{2} \mathrm{O}$. So the catalytic performance of $\mathrm{Ba}_{0.4} \mathrm{Sr}_{0.6} \mathrm{Fe}_{0.6} \mathrm{Mn}_{0.4} \mathrm{O}_{3-\delta}$ was superior to that of $\mathrm{Fe}-\mathrm{K}$ catalyst thanks to the high redox property of the $\mathrm{Ba}_{0.4} \mathrm{Sr}_{0.6} \mathrm{Fe}_{0.6} \mathrm{Mn}_{0.4} \mathrm{O}_{3-\delta}$ perovskite oxide.

Keywords: dehydrogenation of ethylbenzene, perovskite oxide catalyst, redox mechanism, stable under severe conditions, styrene production, lattice oxygen

\section{INTRODUCTION}

Styrene, an important monomer in petrochemistry, is used for polymeric materials such as polystyrene resin, acrylonitrilebutadiene-styrene resin and styrene-butadiene rubber. The production volume of styrene is 30 million tons per year worldwide (Meima and Menon, 2001; Su et al., 2005; Won and Jang, 2011). Styrene is produced via catalytic dehydrogenation of ethylbenzene (EBDH) according to the following chemical equation (Equation 1) (Cavani and Trifirò, 1995).

$$
\mathrm{C}_{8} \mathrm{H}_{10} \rightarrow \mathrm{C}_{8} \mathrm{H}_{8}+\mathrm{H}_{2}
$$

As an endothermic reaction, EBDH requires high temperatures for high conversion of ethylbenzene because of thermodynamic limitations. An iron-based catalyst promoted by potassium and many kinds: $\mathrm{Cr}_{2} \mathrm{O}_{3}, \mathrm{MoO}_{3}, \mathrm{CeO}_{2}$, and $\mathrm{Pd}$ is used as an industrial catalyst (Kearby, 1945; Eggertsen and Voge, 1947; Pitzer, 1958; Lee, 1974; O’Hara, 1975; Riesser, 1979; Hirano, 1986; Rokicki et al., 2004). In the industrial process, steam is supplied with $\mathrm{EB}$ for increasing the equilibrium conversion by decreasing the partial pressure of EB. Additionally, steam has roles of heating up the reactant fluid, supplying heat for the endothermic reaction, and inhibiting coke deposition on the catalyst. A disadvantage of EBDH with steam is a large amount of energy loss because of the supply of superheated steam. Therefore, development of a catalyst that can work under low steam conditions and at low temperatures has been pursued.

For energy resource conservation, oxidative dehydrogenation of ethylbenzene $(\mathrm{ODH})$ has recently been emphasized and investigated widely. Because ODH is an exothermic reaction, high conversion can be achieved at lower temperatures than from nonoxidative dehydrogenation. Meso-structured $\mathrm{CeO}_{2}$ ( $\mathrm{Xu}$ et al., 2009), $\mathrm{V}_{2} \mathrm{O}_{5} / \mathrm{CeO}_{2} / \mathrm{Al}_{2} \mathrm{O}_{3}$ (Reddy et al., 2007), and $\mathrm{Mg}\left(\mathrm{VO}_{4}\right)_{2}$ $\mathrm{MgO}$ (Chang et al., 1995) catalysts were reported as highly active catalysts working at low temperatures of around $723 \mathrm{~K}$ for ODH. Onion-like carbon (Su et al., 2005, 2007, 2010) and carbon fibers (Zhao et al., 2007) have also been reported as catalysts showing high activity for ODH. However, because of the combustion of $\mathrm{EB}$ and styrene, ODH processes presented some problems such as the decrease of selectivity to styrene. Therefore, the selectivity 
to styrene was low in the $\mathrm{ODH}$ process: about $68 \%$ at the $\mathrm{EB}$ conversion rate of $91 \%$ (Keller et al., 2002). An application of $\mathrm{N}_{2} \mathrm{O}$ and $\mathrm{CO}_{2}$ to ethylbenzene dehydrogenation has been conducted to attain high selectivity to styrene, $\mathrm{N}_{2} \mathrm{O}$, and $\mathrm{CO}_{2}$ were used instead of $\mathrm{O}_{2}$ to avoid the combustion of styrene and EB, to CO and $\mathrm{CO}_{2}$ (Sugino et al., 1995; Sakurai et al., 2000a, 2002; Shiju et al., 2005). As for using $\mathrm{N}_{2} \mathrm{O}$ as the oxidant for $\mathrm{ODH}$ of ethylbenzene, high styrene yield was obtained at low temperature, however the selectivity to styrene was low due to the production of styrene oxide as well as benzene and toluene (Shiju et al., 2005). Vislovskiy et al. (2002) and Park et al. (2003) investigated $\mathrm{EBDH}$ in the presence of $\mathrm{CO}_{2}$ over $\mathrm{V}-\mathrm{Sb} / \mathrm{Al}$-oxide catalyst. They stated that a redox-type mechanism proceeded on $\mathrm{V}-\mathrm{Sb} / \mathrm{Al}$-oxide catalyst, which achieved high activity and selectivity to styrene. $\mathrm{CO}_{2}$ was considered to be a desirable oxidant for EBDH. Although high activity and stability was acquired over activated carbon-supported vanadium catalyst which was promising dehydrogenation catalyst, deactivation proceeded on the catalyst due to coke deposition. Sakurai et al. investigated the catalytic properties of V/AC catalyst for $\mathrm{EBDH}$ with $\mathrm{CO}_{2}$ (Sakurai et al., 2000b). The catalyst revealed high activity and selectivity to styrene, but deactivation was not prevented. From these backgrounds, development of a novel dehydrogenation catalyst which has high stability as well as high activity is considered to be required.

We previously investigated the reaction mechanism of $\mathrm{EBDH}$ with steam over the industrial potassium promoted the iron catalyst $(\mathrm{Fe}-\mathrm{K})$ catalyst, and found for the first time that oxidative dehydrogenation of EBDH (Equation 2) proceeded on the $\mathrm{Fe}-\mathrm{K}$ catalyst and $\mathrm{H}_{2} \mathrm{O}$ can regenerate the consumed lattice oxygen in the catalyst (Equation 3) (Sekine et al., 2008).

$$
\begin{array}{r}
\mathrm{C}_{8} \mathrm{H}_{10}+\mathrm{O}_{\text {lat }}^{2-} \rightarrow \mathrm{C}_{8} \mathrm{H}_{8}+\mathrm{H}_{2} \mathrm{O}+V_{o x}+2 \mathrm{e}^{-} \\
\mathrm{H}_{2} \mathrm{O}+V_{o x}+2 \mathrm{e}^{-} \rightarrow \mathrm{H}_{2}+\mathrm{O}_{\text {lat }}^{2-}
\end{array}
$$

Here, $\mathrm{O}_{\text {lat }}^{2-}$ denotes the lattice oxygen and $V_{o x}$ shows the lattice vacancy in the catalyst. In other words, the catalytic activity and stability depended on redox characteristics of the lattice oxygen in the catalyst. Therefore, investigations of catalytic activity for EBDH with steam over some perovskite-type oxides whose mobility of lattice oxygen in perovskite-type oxide could be controlled, were conducted. As a result of investigations, $\mathrm{La}_{0.8} \mathrm{Ba}_{0.2} \mathrm{Fe}_{0.4} \mathrm{Mn}_{0.6} \mathrm{O}_{3-\delta}$ (LBFMO) catalyst had high activity and stability and revealed superior performance to the Fe-K catalyst at $813 \mathrm{~K}$ (Watanabe et al., 2009). In addition, we found that oxidative dehydrogenation using lattice oxygen (Equation 2) proceeded and $\mathrm{H}_{2} \mathrm{O}$ could regenerate the consumed lattice oxygen in the catalyst (Equation 3). The high regeneration rate of lattice oxygen enhanced the activity and stability of EBDH (Watanabe et al., 2011).

However, elemental La contained in LBFMO catalyst is an expensive rare-earth metal that is distributed unevenly throughout the world. Therefore, lanthanoid elements such as La are best not included in the catalyst for industrial applications. Additionally, the catalyst must work under low reaction temperatures and low steam conditions from the viewpoint of energy saving. These severe operations might be possible thanks to high redox property of perovskite-type oxides, which could achieve a low-cost dehydrogenation process.

In this work, to develop a novel La-free perovskite-type oxide catalyst, $\mathrm{BaMnO}_{3}-\delta$-based catalysts that are well known for high redox properties, were applied to EBDH with steam. For acquiring high-activity catalysts, the low-valence metal ion such as $\mathrm{Ba}^{2+}$, $\mathrm{Sr}^{2+}$, or $\mathrm{Ca}^{2+}$ was incorporated in A-site in the structure. The valence of B-site cation was fixed at higher-valence state for keeping the charge neutralization conditions by introduction of the low-valence metal ion in A-site, which affected enhancement of the catalytic property of the catalyst. In addition, introducing the low-valence metal ion into the A-site in perovskite was expected to produce oxygen vacancies in the structure, and it would bring high oxygen ionic conductivity. We optimized the structure of the $\mathrm{BaMnO}_{3}-\delta$-based catalyst by the substitution of A-site with $\mathrm{Sr}$ and B-site with Fe. Additionally, the activity and robustness of the optimized catalyst at low reaction temperature and low steam/EB condition were examined for exploring the possibility as the industrial catalyst.

\section{EXPERIMENTAL \\ CATALYST PREPARATION}

Screening tests revealed that $\mathrm{Ba}-\mathrm{Ca}-\mathrm{Fe}-\mathrm{Mn}-\mathrm{Ox}$ and $\mathrm{Ba}-\mathrm{Sr}-$ Fe-Mn-Ox perovskite were active and selective catalysts for EBDH as shown in Table 1. Therefore, we used some perovskite oxides in this study: $\mathrm{Ba}_{0.2} \mathrm{Ca}_{0.8} \mathrm{Fe}_{0.4} \mathrm{Mn}_{0.6} \mathrm{O}_{3-\delta}$ and $\mathrm{Ba}_{1-x} \mathrm{Sr}_{x} \mathrm{Fe}_{y} \mathrm{Mn}_{1-y} \mathrm{O}_{3-\delta}(x=0,0.2,0.4,0.6,0.8$, and $1, y=$ $0,0.2,0.4,0.6$, and 0.8$)$. They were prepared using a complex polymerization method as follows: $\mathrm{Ba}\left(\mathrm{NO}_{3}\right)_{2}, \mathrm{Sr}\left(\mathrm{NO}_{3}\right)_{2}$, (or $\left.\mathrm{Ca}\left(\mathrm{NO}_{3}\right)_{2} \cdot 4 \mathrm{H}_{2} \mathrm{O}\right), \mathrm{Fe}\left(\mathrm{NO}_{3}\right)_{2} \cdot 9 \mathrm{H}_{2} \mathrm{O}$, and $\mathrm{Mn}\left(\mathrm{NO}_{3}\right)_{2} \cdot 6 \mathrm{H}_{2} \mathrm{O}$ (Kanto Kagaku) were dissolved in distilled water. Then, citric acid and ethylene glycol were added to the solution to produce a molar ratio of total metal ions: citric acid: ethylene glycol $=1: 3: 3$. The obtained solution was dried up to produce a gel at $353 \mathrm{~K}$. Then the gel was pre-calcined at $673 \mathrm{~K}$ for $2 \mathrm{~h}$, and then calcined at $1123 \mathrm{~K}$ for $10 \mathrm{~h}$.

\section{CHARACTERIZATION OF THE CATALYST}

The crystalline structure of the prepared catalyst was ascertained using X-ray powder diffraction with $\mathrm{CuK} \alpha$ radiation $(\lambda=$ 1.54 $\AA$, Rint-2000; Rigaku Corp.). The specific surface area of perovskite oxide was measured using $\mathrm{N}_{2}$ adsorption at $77 \mathrm{~K}$ using Autosorb-1 (Quantachrome Corp.). The sample was outgassed at

Table 1 | EB conversion and selectivity to products for EBDH over

\begin{tabular}{|c|c|c|c|c|}
\hline \multirow[t]{2}{*}{ Catalyst } & \multirow{2}{*}{$\begin{array}{l}\text { EB } \\
\text { Conv./\% } \\
(0.5 \mathrm{~h})\end{array}$} & \multicolumn{3}{|c|}{ Selectivity $(0.5 \mathrm{~h}) / \%$} \\
\hline & & Styrene & Benzene & Toluene \\
\hline $\mathrm{CaFe}_{0.4} \mathrm{Mn}_{0.6} \mathrm{O}_{3-\delta}$ & 4.9 & 77.9 & 17.3 & 4.8 \\
\hline $\mathrm{SrFe}_{0.4} \mathrm{Mn}_{0.6} \mathrm{O}_{3-\delta}$ & 17.1 & 91.9 & 6.5 & 1.7 \\
\hline $\mathrm{BaFe}_{0.4} \mathrm{Mn}_{0.6} \mathrm{O}_{3-\delta}$ & 33.2 & 94.4 & 2.4 & 3.2 \\
\hline $\mathrm{Ba}_{0.2} \mathrm{Ca}_{0.8} \mathrm{Fe}_{0.4} \mathrm{Mn}_{0.6} \mathrm{O}_{3-\delta}$ & 28.2 & 96.6 & 2.0 & 1.4 \\
\hline $\mathrm{Ba}_{0.2} \mathrm{Sr}_{0.8} \mathrm{Fe}_{0.4} \mathrm{Mn}_{0.6} \mathrm{O}_{3-\delta}$ & 28.8 & 95.4 & 2.9 & 1.7 \\
\hline
\end{tabular}
perovskite catalysts. 
$573 \mathrm{~K}$ for $2 \mathrm{~h}$ before $\mathrm{N}_{2}$ adsorption. Redox property of the catalyst was measured using thermogravimetric analysis with TGA-50 (Shimadzu Corp.). The catalyst sample was set on the center of the muffle. Then the temperature of the catalyst was raised with a $10 \mathrm{~K} \mathrm{~min}^{-1}$ heating rate from room temperature to $783 \mathrm{~K}$ in $\mathrm{N}_{2}$ atmosphere. Thermogravimetric measurements were conducted under 10 vol\% $\mathrm{H}_{2}$ in $\mathrm{N}_{2}$ atmosphere and also conducted under 10 vol $\% \mathrm{H}_{2}+1$ vol $\% \mathrm{H}_{2} \mathrm{O}$ or 2.5 vol $\% \mathrm{H}_{2} \mathrm{O}$ in $\mathrm{N}_{2}$ atmosphere at $783 \mathrm{~K}$ to elucidate the effect of steam on the reduction profile of the catalyst. Weight loss " 0 " was the starting weight of the catalyst.

\section{ACTIVITY TEST}

Catalytic activity, selectivities to products and stability were examined in a conventional fixed bed reactor. The reactor used for this study comprised a quartz tube (10-mm o.d.) containing a catalyst bed, which was fixed by quartz wool. A type-K thermocouple enclosed in a quartz thermowell (3-mm o.d.) was positioned inside the catalyst bed for the measurement of the catalyst temperature. Reactions were conducted at 783 or $813 \mathrm{~K}$ at atmospheric pressure in the presence of steam; the molar ratio of steam to ethylbenzene was 2 or 12 . The weight hourly space velocity (WHSV) was $1.2 \mathrm{~h}^{-1}$; the catalyst weight was $1 \mathrm{~g}$. Liquid products such as ethylbenzene, benzene, toluene, and styrene were analyzed using off-line flame ionization detection (FID) gas chromatograph (GC-2014; Shimadzu Corp.). Gaseous products such as $\mathrm{H}_{2}, \mathrm{CO}$, and $\mathrm{CH}_{4}$ were analyzed using off-line thermal conductivity detection (TCD) gas chromatograph (GC-8A; Shimadzu Corp.). The conversion (Equation 4) and styrene yield (Equation 5) were evaluated using following equations.

$$
\begin{aligned}
\text { EB conversion }[/ \%]= & ([\text { Sty }]+[\mathrm{Bz}]+[\mathrm{Tol}]) /([\mathrm{EB}]+[\text { Sty }] \\
& +[\mathrm{Bz}]+[\mathrm{Tol}])^{*} 100 \\
\text { Styrene yield }[/ \%]= & {[\text { Sty }] /([\mathrm{Sty}]+[\mathrm{Bz}]} \\
& +[\mathrm{Tol}])^{*}(\text { EBconversion })
\end{aligned}
$$

Styrene selectivity $[/ \%]=[$ Sty $] /([\text { Sty }]+[\mathrm{Bz}]+[\mathrm{Tol}])^{*} 100$

Here, $[\mathrm{EB}],[\mathrm{Sty}],[\mathrm{Bz}]$, and $[\mathrm{Tol}]$ were, respectively, the concentration of $\mathrm{EB}$, styrene, benzene and toluene in the effluent gas. Carbon balances in this work were over 95\% through all the experimentally obtained results.

\section{XPS MEASUREMENT FOR CHARACTERIZATION OF CATALYST SURFACE}

X-ray photoelectron spectroscopy (XPS, ESCA1800; Ulvac-Phi Inc.) measurement was performed using a non-monochromatic $\mathrm{Al}-\mathrm{K} \alpha$ radiation. The pass energy of the analyzer was set at $23.5 \mathrm{eV}$. Binding energies obtained for an identical sample were reproducible within $\pm 0.1 \mathrm{eV}$ in general. Binding energy of C1s was corrected at $284.7 \mathrm{eV}$.

\section{SURFACE EXCHANGE REACTION}

For clarifying redox properties of perovskite catalyst, surface exchange reaction using isotope was performed as the following method. First, $100 \%$ of $\mathrm{H}_{2}^{16} \mathrm{O}$ was supplied to the catalyst for
$30 \mathrm{~min}$ in order to fill ${ }^{16} \mathrm{O}^{2-}$ in the perovskite. After adequately feeding $\mathrm{H}_{2}^{16} \mathrm{O}$ in the catalyst, the mixed gas of $\mathrm{H}_{2}^{18} \mathrm{O}(30 \%)$ and $\mathrm{H}_{2}^{16} \mathrm{O}(70 \%)$ was fed to the catalyst as a step at $783 \mathrm{~K}$ for substitution of lattice oxygen from ${ }^{16} \mathrm{O}^{2-}$ to ${ }^{18} \mathrm{O}^{2-}$. Temporal changes of concentrations of $\mathrm{H}_{2}^{18} \mathrm{O}$ and $\mathrm{H}_{2}^{16} \mathrm{O}$ were monitored using a quadruple mass spectrometer (Q-Mass).

\section{RESULTS AND DISCUSSION}

\section{DEHYDROGENATION ACTIVITY AND SELECTIVITY TO PRODUCTS OVER $\mathrm{BaMnO}_{3}-\delta$-BASED CATALYSTS}

Previous studies revealed that $\mathrm{Mn}$-based and Fe/Mn-oxide catalysts showed high activity for EBDH thanks to the well-balanced rates of release and regeneration of lattice oxygen (Watanabe et al., 2009,2011 ). In addition, Ba-based perovskite was well known to give better performance for oxygen-ion diffusivity (Wang et al., 2005; Vente et al., 2006; Zeng et al., 2007; Cheng et al., 2008). As mentioned in the introduction, high oxygen ionic conductivity was obtained by incorporating low-valence metal ions, such as $\mathrm{Ba}^{2+}, \mathrm{Sr}^{2+}$, and $\mathrm{Ca}^{2+}$ into the A-site in perovskite-type oxides. As shown in Table 1, $\mathrm{BaMnO}_{3-\delta}$-based catalysts showed high activity, compared with $\mathrm{CaMnO}_{3}-\delta$-based and $\mathrm{SrMnO}_{3}-\delta^{-}$ based catalyst. Incorporation of the alkaline earth metal of $\mathrm{Ba}$ in perovskite structure would lead to the generation of electron holes and oxygen vacancies as the charge compensation, which could induce the high oxygen mobility derived from the mixed conduction by electrons and oxygen ions. Also, the incorporation of $\mathrm{Ba}$ in perovskite structure would engender the large free volume in the lattice, which could decrease the activation energy of oxygen ion migration. Therefore, to develop novel La-free perovskite catalysts for $\mathrm{EBDH}, \mathrm{BaMnO}_{3}-\delta$-based perovskite oxides were applied as catalysts.

Table 2 presents results for catalytic activities over $\mathrm{BaMnO}_{3-\delta}, \quad \mathrm{Ba}_{0.2} \mathrm{Sr}_{0.8} \mathrm{MnO}_{3-\delta}$, and $\mathrm{Ba}_{0.2} \mathrm{~A}_{0.8} \mathrm{Fe}_{0.4} \mathrm{Mn}_{0.6}$ $\mathrm{O}_{3-\delta}\left(\mathrm{A}=\mathrm{Ca}^{2+}, \mathrm{Sr}^{2+}\right)$ at $813 \mathrm{~K}$ with the steam/EB molar ratio of 12. Styrene yield over $\mathrm{BaMnO}_{3-\delta}, \mathrm{Ba}_{0.2} \mathrm{Sr}_{0.8} \mathrm{MnO}_{3-\delta}$, $\mathrm{Ba}_{0.2} \mathrm{Ca}_{0.8} \mathrm{Fe}_{0.4} \mathrm{Mn}_{0.6} \mathrm{O}_{3-\delta}$, and $\mathrm{Ba}_{0.2} \mathrm{Sr}_{0.8} \mathrm{Fe}_{0.4} \mathrm{Mn}_{0.6} \mathrm{O}_{3-\delta}$ catalysts at $0.5 \mathrm{~h}$ were, respectively 22.0, 27.1, 26.9, and $27.5 \%$. $\mathrm{BaMnO}_{3}-\delta$-based catalysts showed high activity for $\mathrm{EBDH}$.

\begin{tabular}{|c|c|c|}
\hline Catalyst & Durability* & $\begin{array}{l}\text { Amount of } \\
\text { carbon } \\
\text { deposition } / \mathrm{mg} \\
\text { g-cat }^{-1}\end{array}$ \\
\hline $\mathrm{BaFe}_{0.4} \mathrm{Mn}_{0.6} \mathrm{O}_{3-\delta}$ & 0.48 & 6.4 \\
\hline $\mathrm{Ba}_{0.8} \mathrm{Sr}_{0.2} \mathrm{Fe}_{0.4} \mathrm{Mn}_{0.6} \mathrm{O}_{3-\delta}$ & 0.37 & 7.4 \\
\hline $\mathrm{Ba}_{0.6} \mathrm{Sr}_{0.4} \mathrm{Fe}_{0.4} \mathrm{Mn}_{0.6} \mathrm{O}_{3-\delta}$ & 0.46 & 4.6 \\
\hline $\mathrm{Ba}_{0.4} \mathrm{Sr}_{0.6} \mathrm{Fe}_{0.4} \mathrm{Mn}_{0.6} \mathrm{O}_{3-\delta}$ & 0.59 & 4.8 \\
\hline $\mathrm{Ba}_{0.2} \mathrm{Sr}_{0.8} \mathrm{Fe}_{0.4} \mathrm{Mn}_{0.6} \mathrm{O}_{3-\delta}$ & 0.65 & 5.8 \\
\hline $\mathrm{SrFe}_{0.4} \mathrm{Mn}_{0.6} \mathrm{O}_{3-\delta}$ & 0.60 & 7.6 \\
\hline
\end{tabular}
The substitution of $\mathrm{Sr}^{2+}$ for $\mathrm{Ba}^{2+}$ enhanced dehydrogenation activity; however, the stability was not improved by the substitution. The reason for improving high catalytic activity by

${ }^{*}$ Durability $=$ Styrene yield at $2 \mathrm{~h} /$ Styrene yield at $0.5 \mathrm{~h}$. 
the substitution of $\mathrm{Sr}^{2+}$ for $\mathrm{Ba}^{2+}$ might be enhancement of high releasing rate of lattice oxygen (Equation 2). In other words, ionic conductivity might increase by the substitution of $\mathrm{Sr}^{2+}$. Shao et al. investigated the $\mathrm{O}_{2}$ permeability property of $\mathrm{Ba}_{x} \mathrm{Sr}_{1-x} \mathrm{Co}_{0.8} \mathrm{Fe}_{0.2} \mathrm{O}_{3-\delta}(x=0-1)$ perovskite membrane (Shao et al., 2001). They concluded that there existed an optimal value of $\mathrm{Ba}^{2+}$ substitution ratio $(x=0.3)$ in terms of $\mathrm{O}_{2}$ permeability because of the low activation energy of oxygen transportation in $\mathrm{Ba}_{0.3} \mathrm{Sr}_{0.7} \mathrm{Co}_{0.8} \mathrm{Fe}_{0.2} \mathrm{O}_{3}-\delta$ perovskite membrane. The slightly substitution of $\mathrm{Sr}^{2+}$ for $\mathrm{Ba}^{2+}$ might decrease an activation energy for releasing rate of lattice oxygen. Therefore, initial dehydrogenation activity of the $\mathrm{Ba}_{0.2} \mathrm{Sr}_{0.8} \mathrm{MnO}_{3-\delta}$ catalyst was higher that of the $\mathrm{BaMnO}_{3}-\delta$ catalyst. However, the rate for regenerating lattice oxygen (Equation 3 ) might not be improved, so stability was not improved.

While, the substitution of $\mathrm{Fe}$ for $\mathrm{Mn}$ improved the stability, and the initial activity showed similar values on $\mathrm{Ba}_{0.2} \mathrm{Sr}_{0.8} \mathrm{MnO}_{3-\delta}$, and $\mathrm{Ba}_{0.2} \mathrm{Sr}_{0.8} \mathrm{Fe}_{0.4} \mathrm{Mn}_{0.6} \mathrm{O}_{3-\delta}$ catalysts. Comparison of the catalytic performance between $\mathrm{Ba}_{0.2} \mathrm{Ca}_{0.8} \mathrm{Fe}_{0.4} \mathrm{Mn}_{0.6} \mathrm{O}_{3-\delta}$ and $\mathrm{Ba}_{0.2} \mathrm{Sr}_{0.8} \mathrm{Fe}_{0.4} \mathrm{Mn}_{0.6} \mathrm{O}_{3-\delta}$, a catalyst substituted with $\mathrm{Sr}\left(\mathrm{Ba}_{0.2} \mathrm{Sr}_{0.8} \mathrm{Fe}_{0.4} \mathrm{Mn}_{0.6} \mathrm{O}_{3-\delta}\right)$ showed better activity and stability. $\mathrm{Ba}_{0.2} \mathrm{Sr}_{0.8} \mathrm{Fe}_{0.4} \mathrm{Mn}_{0.6} \mathrm{O}_{3-\delta}$ catalyst showed comparable initial activity with Fe-K catalyst. The incorporation of $\mathrm{Fe}$ in perovskite-type oxide was found to suppress the lattice oxygen release (Equation 2) and promote the lattice oxygen regeneration (Equation 3) in the previous investigation (Watanabe et al., 2011). Therefore, the Fe/Mn-oxide catalyst showed higher stability for $\mathrm{EBDH}$ than Mn-based oxide thanks to the well-balanced rates of release and regeneration of lattice oxygen.

Styrene selectivity over $\mathrm{Ba}_{0.2} \mathrm{Sr}_{0.8} \mathrm{MnO}_{3-\delta}$ catalyst was $94.1 \%$ and that over $\mathrm{Ba}_{0.2} \mathrm{Sr}_{0.8} \mathrm{Fe}_{0.4} \mathrm{Mn}_{0.6} \mathrm{O}_{3-\delta}$ was $95.4 \%$. Introducing $\mathrm{Fe}$ in the B-site of $\mathrm{Ba}_{0.2} \mathrm{Sr}_{0.8} \mathrm{MnO}_{3} \delta$ perovskite catalyst enhanced the activity, stability, and selectivity to styrene. After $2 \mathrm{~h}$ of reaction, styrene selectivity was improved a little. The reason for improvement of the styrene selectivity of all catalysts in Table 3 after $2 \mathrm{~h}$ of reaction was that the formation rate of benzene and toluene degraded faster than that of styrene formation rate. Further investigations by optimizing the structure of

Table 3 | Catalytic performances for EBDH over perovskite catalysts: reaction times.

\begin{tabular}{|c|c|c|c|c|c|}
\hline \multirow[t]{2}{*}{ Catalyst } & \multirow{2}{*}{$\begin{array}{l}\text { BET specific } \\
\text { surface } \\
\text { area } / \mathbf{m}^{2} \mathbf{g}^{-1}\end{array}$} & \multicolumn{2}{|c|}{$\begin{array}{l}\text { Styrene } \\
\text { yield } / \%\end{array}$} & \multicolumn{2}{|c|}{$\begin{array}{c}\text { Styrene } \\
\text { selectivity/\% }\end{array}$} \\
\hline & & at $0.5 \mathrm{~h}$ & at $2.0 \mathrm{~h}$ & at $0.5 \mathrm{~h}$ & at $2.0 \mathrm{~h}$ \\
\hline $\mathrm{BaMnO}_{3-\delta}$ & 2.8 & 22.0 & 5.1 & 94.5 & 96.0 \\
\hline $\begin{array}{l}\mathrm{Ba}_{0.2} \mathrm{Sr}_{0.8} \\
\mathrm{MnO}_{3-\delta}\end{array}$ & 8.4 & 27.1 & 3.6 & 94.1 & 94.0 \\
\hline $\begin{array}{l}\mathrm{Ba}_{0.2} \mathrm{Ca}_{0.8} \\
\mathrm{Fe}_{0.4} \mathrm{Mn}_{0.6} \mathrm{O}_{3-\delta}\end{array}$ & 9.7 & 26.9 & 13.2 & 96.6 & 97.8 \\
\hline $\begin{array}{l}\mathrm{Ba}_{0.2} \mathrm{Sr}_{0.8} \\
\mathrm{Fe}_{0.4} \mathrm{Mn}_{0.6} \mathrm{O}_{3-\delta}\end{array}$ & 13.1 & 27.5 & 17.9 & 95.4 & 97.8 \\
\hline $\mathrm{Fe}-\mathrm{K}$ & 2.0 & 27.1 & 29.4 & 97.8 & 98.3 \\
\hline
\end{tabular}

$\mathrm{Ba}-\mathrm{Sr}-\mathrm{Fe}-\mathrm{Mn}$-perovskite catalyst were conducted to improve the activity/selectivity to styrene.

\section{OPTIMIZATION OF A-SITE SUBSTITUTION RATIO OF $\mathrm{Sr}^{2+}$ FOR Ba ${ }^{2+}$ IN $\mathrm{Ba}_{1-x} \mathrm{Sr}_{\boldsymbol{x}} \mathrm{Fe}_{0.4} \mathrm{Mn}_{\mathbf{0 . 6}} \mathbf{O}_{3}-\delta$ CATALYST FOR EBDH}

We investigated A-site substitution ratio $(=x)$ in $\mathrm{Ba}_{1-x} \mathrm{Sr}_{x} \mathrm{Fe}_{0.4} \mathrm{Mn}_{0.6} \mathrm{O}_{3-\delta} \quad(x=0,0.2,0.4,0.6,0.8$, and 1$)$ catalysts on the activity/selectivity for EBDH. Figure 1 and Table 4 portray the results of the activity test. As for the activity and stability of these catalysts, these perovskite catalysts deactivated gradually. The stability was increased with high $\mathrm{Sr}^{2+}$ content of 0.6 or 0.8 in the catalyst. Then the relation among stability, amount of carbon deposition, and the structure of catalyst was examined. First, temperature-programmed

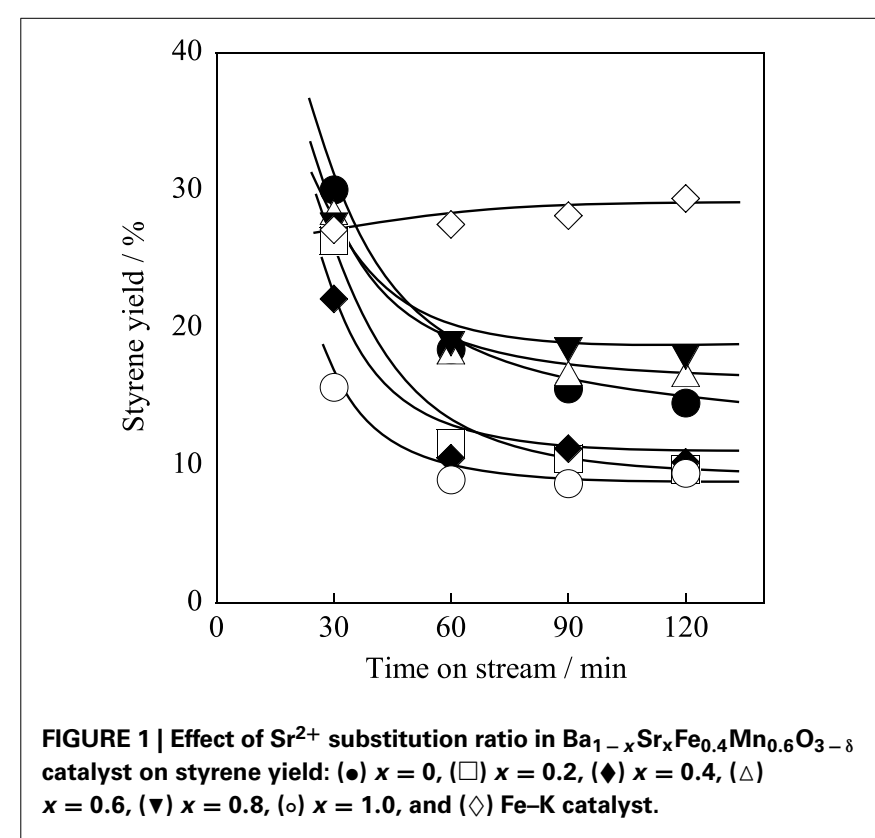

Table 4 | Selectivity to styrene, benzene and toluene for EBDH over $\mathrm{Ba}_{1-x} \mathrm{Sr}_{x} \mathrm{Fe}_{0.4} \mathrm{Mn}_{0.6} \mathrm{O}_{3-\delta}(0 \leq x \leq 1)$ catalysts and Fe-K catalyst.

\begin{tabular}{|c|c|c|c|c|c|c|c|}
\hline \multirow[t]{2}{*}{ Catalyst } & \multirow{2}{*}{$\begin{array}{l}\text { BET specific } \\
\text { surface } \\
\text { area } / \mathrm{m}^{2} \mathbf{g}^{-1}\end{array}$} & \multicolumn{3}{|c|}{$\begin{array}{c}\text { Selectivity } \\
(0.5 \text { h }) / \%\end{array}$} & \multicolumn{3}{|c|}{$\begin{array}{c}\text { Selectivity } \\
(2 \mathrm{~h}) / \%\end{array}$} \\
\hline & & Sty & $\mathrm{Bz}$ & Tol & Sty & $\mathrm{Bz}$ & Tol \\
\hline $\begin{array}{l}\mathrm{BaFe}_{0.4} \mathrm{Mn}_{0.6} \\
\mathrm{O}_{3-\delta}\end{array}$ & 7.1 & 94.3 & 2.0 & 3.7 & 97.0 & 1.1 & 1.9 \\
\hline $\begin{array}{l}\mathrm{Ba}_{0.8} \mathrm{Sr}_{0.2} \mathrm{Fe}_{0.4} \\
\mathrm{Mn}_{0.6} \mathrm{O}_{3-\delta}\end{array}$ & 6.5 & 95.2 & 2.6 & 2.2 & 96.9 & 0.8 & 2.4 \\
\hline $\begin{array}{l}\mathrm{Ba}_{0.6} \mathrm{Sr}_{0.4} \mathrm{Fe}_{0.4} \\
\mathrm{Mn}_{0.6} \mathrm{O}_{3-\delta}\end{array}$ & 7.9 & 96.3 & 2.1 & 1.6 & 97.6 & 0.5 & 1.9 \\
\hline $\begin{array}{l}\mathrm{Ba}_{0.4} \mathrm{Sr}_{0.6} \mathrm{Fe}_{0.4} \\
\mathrm{Mn}_{0.6} \mathrm{O}_{3-\delta}\end{array}$ & 9.0 & 96.1 & 2.4 & 1.5 & 98.0 & 0.4 & 1.6 \\
\hline $\begin{array}{l}\mathrm{Ba}_{0.2} \mathrm{Sr}_{0.8} \mathrm{Fe}_{0.4} \\
\mathrm{Mn}_{0.6} \mathrm{O}_{3-\delta}\end{array}$ & 13.1 & 95.4 & 2.9 & 1.7 & 97.8 & 0.6 & 1.7 \\
\hline $\begin{array}{l}\mathrm{SrFe}_{0.4} \mathrm{Mn}_{0.6} \\
\mathrm{O}_{3-\delta}\end{array}$ & 11.6 & 91.9 & 6.5 & 1.7 & 97.0 & 0.8 & 2.2 \\
\hline $\mathrm{Fe}-\mathrm{K}$ & 2.0 & 97.8 & 1.1 & 1.1 & 98.3 & 0.9 & 0.8 \\
\hline
\end{tabular}


oxidation was conducted to measure the amount of carbon deposition over $\mathrm{Ba}_{1-x} \mathrm{Sr}_{\mathrm{x}} \mathrm{Fe}_{0.4} \mathrm{Mn}_{0.6} \mathrm{O}_{3-\delta}(0 \leq x \leq 1)$ catalysts after $2 \mathrm{~h}$ reaction. Results showed that the amount of deposited carbon was very little for each catalyst about $5 \mathrm{mg} \mathrm{g-cat}{ }^{-1}$, and no relation was found between stability and the amount of carbon deposition as shown in Table 2. Therefore, carbon deposition does not seem to be the reason for deactivation of the catalyst. Next, the structure of as-made and used catalysts was evaluated using XRD. Figures $2 A, B$ respectively depict XRD patterns of $\mathrm{Ba}_{1-x} \mathrm{Sr}_{\mathrm{x}} \mathrm{Fe}_{0.4} \mathrm{Mn}_{0.6} \mathrm{O}_{3-\delta} \quad(0 \leq x \leq 0.4)$ catalysts and of $\mathrm{Ba}_{1-x} \mathrm{Sr}_{x} \mathrm{Fe}_{0.4} \mathrm{Mn}_{0.6} \mathrm{O}_{3-\delta} \quad(0.6 \leq x \leq 1)$ catalysts. From Figures 2A,B, the peak position was shifted between the fresh catalyst and used one. The shift in peak position seemed to be caused by producing oxygen vacancies. Figure $2 \mathrm{~A}$ shows the XRD patterns of $\mathrm{Ba}_{1-x} \mathrm{Sr}_{\mathrm{x}} \mathrm{Fe}_{0.4} \mathrm{Mn}_{0.6} \mathrm{O}_{3}-\delta$ $(0 \leq x \leq 0.4)$ catalysts include $\mathrm{BaMnO}_{3}$ and $\mathrm{BaMnO}_{3}-\delta$ after $2 \mathrm{~h}$ reaction. $\mathrm{BaMnO}_{3-\delta}$ perovskite structure had lattice vacancy in the structure. However, the structure of used $\mathrm{Ba}_{1-x} \mathrm{Sr}_{x} \mathrm{Fe}_{0.4} \mathrm{Mn}_{0.6} \mathrm{O}_{3-\delta}(0.6 \leq x \leq 1)$ catalysts were almost identical structures to those of as-made catalyst derived from $\mathrm{SrMnO}_{3}$ structure from Figure 2B. For Figure 2A at about $2 \theta=$ $24^{\circ}$, small peak was observed after reaction, although the peak was not observed over the as-made catalyst. The appeared peak was attributable to the $\mathrm{BaMnO}_{3}-\delta$ structure. The reason for the
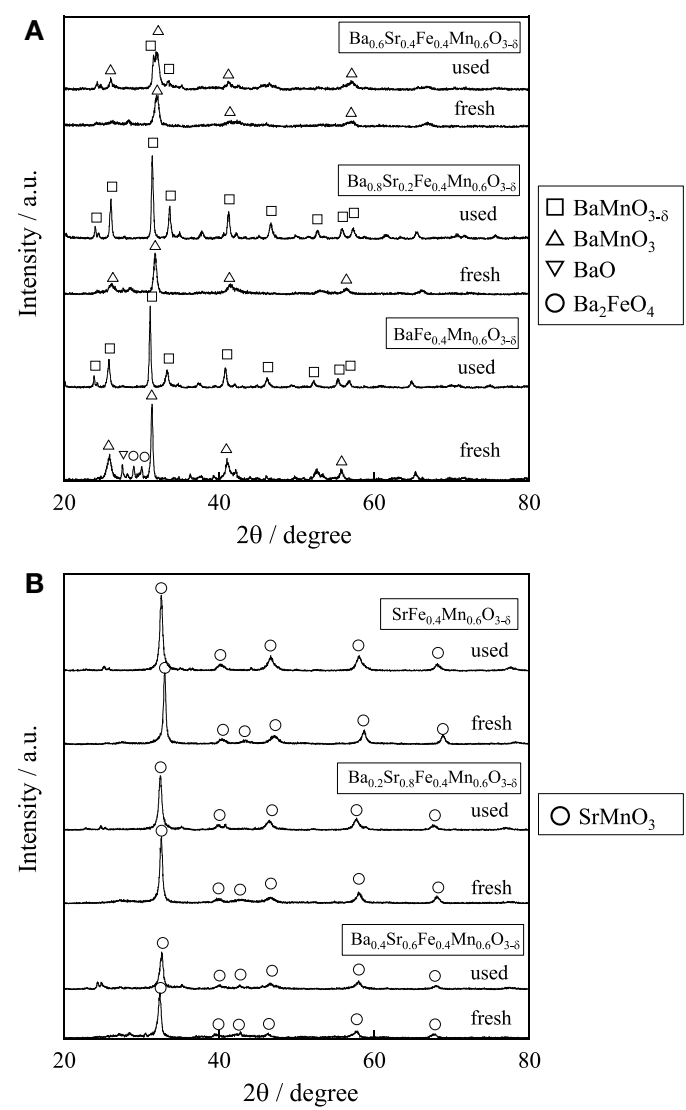

FIGURE 2 | XRD patterns for (A) $\mathrm{Ba}_{1-x} \mathrm{Sr}_{x} \mathrm{Fe}_{0.4} \mathrm{Mn}_{0.6} \mathrm{O}_{3-\delta}(0 \leq x \leq 0.4)$ catalysts and (B) $\mathrm{Ba}_{1-x} \mathrm{Sr}_{x} \mathrm{Fe}_{0.4} \mathrm{Mn}_{0.6} \mathrm{O}_{3-\delta}(0.6 \leq x \leq 1)$ catalysts. appearance of small peak was the difference of sharing state of perovskite unit cell. The as-made catalyst has a cubic type structure with corner-sharing $\mathrm{MnO}_{6}$ octahedral. In contrast to the stoichiometric $\mathrm{BaMnO}_{3}$, oxygen-deficient $\mathrm{BaMnO}_{3}-\delta$ has different hexagonal/rhombohedral structures with variable ratios of corner-sharing (cubic) and face-sharing (hexagonal) layers (Adkin and Hayward, 2006, 2007). These differences produced the new peak after dehydrogenation reaction. Such created lattice vacancy under dehydrogenation atmosphere might be due to the fact that the release rate of lattice oxygen (Equation 2) was higher than the regeneration rate of lattice oxygen. Therefore, lattice oxygen in $\mathrm{BaMnO}_{3}$ was consumed and the $\mathrm{BaMnO}_{3}-\delta$ structure appeared. However, lattice vacancy was not created by low content of $\mathrm{Ba}^{2+}$ in the perovskite, as shown in Figure 2B. This fact might be explained by the well-balanced rates of release and regeneration of lattice oxygen. Therefore, the imbalance of release rate and regeneration rate of lattice oxygen is attributable to the deactivation of the catalyst and change of structure attributable to the reduction by $\mathrm{EB}$ on $\mathrm{Ba}_{1-x} \mathrm{Sr}_{x} \mathrm{Fe}_{0.4} \mathrm{Mn}_{0.6} \mathrm{O}_{3-\delta}(0 \leq x \leq 0.4)$.

From these results and consideration, the $\mathrm{Sr}^{2+}$ substitution ratio of 0.6 was better in terms of high initial activity and stability for EBDH. However, Fe-K industrial catalyst still shows higher stability, as described above. Therefore, we controlled the stability by changing the substitution amount of $\mathrm{Fe}$ in $\mathrm{Ba}_{0.4} \mathrm{Sr}_{0.6} \mathrm{Fe}_{y} \mathrm{Mn}_{1-y} \mathrm{O}_{3-\delta}(0.2 \leq y \leq 0.8)$ catalysts in the next section.

\section{OPTIMIZATION OF B-SITE SUBSTITUTION RATIO IN $\mathrm{Ba}_{0.4} \mathrm{Sr}_{0.6} \mathrm{Fe}_{y} \mathrm{Mn}_{1-y} \mathbf{0}_{3-\delta}$ CATALYST FOR EBDH}

For further enhancement of stability, the Fe substitution ratio $(y)$ in $\mathrm{Ba}_{0.4} \mathrm{Sr}_{0.6} \mathrm{Fe}_{y} \mathrm{Mn}_{1-y} \mathrm{O}_{3-\delta}$ was optimized. Activity tests were performed over $\mathrm{Ba}_{0.4} \mathrm{Sr}_{0.6} \mathrm{Fe}_{y} \mathrm{Mn}_{1-y} \mathrm{O}_{3-\delta} \quad(y=0.2,0.4$, 0.6 , and 0.8 ) catalysts at $813 \mathrm{~K}$. Figure 3 shows the styrene yield as a function of reaction time. Results showed that

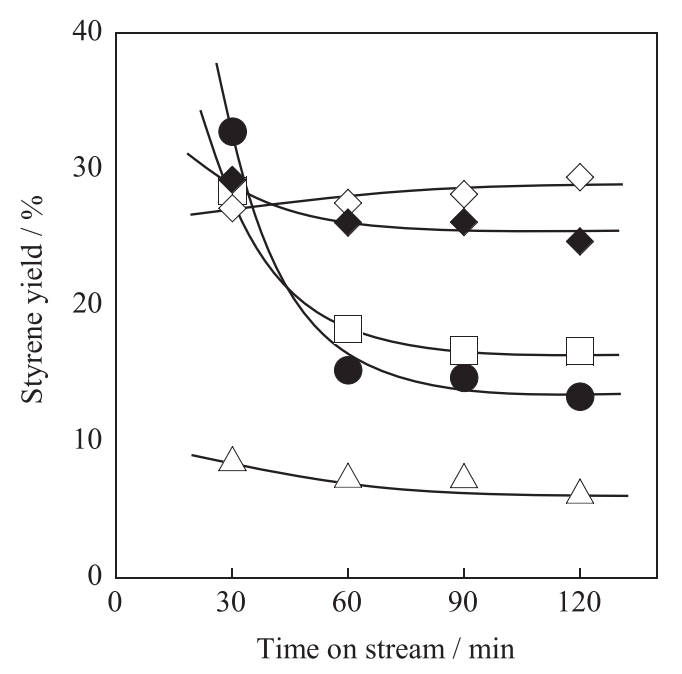

FIGURE 3 | Effect of Fe cation substitution ratio in $\mathrm{Ba}_{0.4} \mathrm{Sr}_{0.6} \mathrm{Fe}_{y}$ $\mathrm{Mn}_{1-y} \mathrm{O}_{3-\delta}$ catalyst on styrene yield: $(\bullet) y=0.2,(\square) y=0.4,(\diamond)$ $y=0.6,(\Delta) y=0.8$, and $(\diamond) \mathrm{Fe}-\mathrm{K}$ catalysts. 
the stability was enhanced with increasing Fe cation substitution ratio, as we expected. Figures $4 \mathrm{~A}, \mathrm{~B}$ show XRD patterns for these catalysts. As-made $\mathrm{Ba}_{0.4} \mathrm{Sr}_{0.6} \mathrm{Fe}_{0.2} \mathrm{Mn}_{0.8} \mathrm{O}_{3-\delta}$ catalyst contained perovskite-type oxide and undesired $\mathrm{BaFe}_{2} \mathrm{O}_{4}$ phase. After $2 \mathrm{~h}$ reaction, $\mathrm{Ba}_{0.4} \mathrm{Sr}_{0.6} \mathrm{Fe}_{0.2} \mathrm{Mn}_{0.8} \mathrm{O}_{3-\delta}$ catalyst contained many impurity phases because $\mathrm{EB}$ reduced the catalyst during the reaction by imbalance of release rate and the regeneration rate of lattice oxygen. However, asmade $\mathrm{Ba}_{0.4} \mathrm{Sr}_{0.6} \mathrm{Fe}_{y} \mathrm{Mn}_{1-y} \mathrm{O}_{3-\delta}(y=0.4,0.6$, and 0.8$)$ catalysts showed characteristic peaks for perovskite-type oxide. After EBDH reaction, $\mathrm{Ba}_{0.4} \mathrm{Sr}_{0.6} \mathrm{Fe}_{y} \mathrm{Mn}_{1-y} \mathrm{O}_{3-\delta}(y=0.4,0.6$, and 0.8$)$ catalysts showed almost identical structure to that of the as-made catalyst. Enhancement of stability was regarded as improving the regenerating rate of lattice oxygen by Fe substitution.

Table 5 presents the effect of the Fe substitution with Mn on the selectivity to products. Fe substitution increased selectivity to benzene and decreased selectivity to toluene slightly, although styrene selectivity did not change from $y=0.2$ to $y=0.6$ on $\mathrm{Ba}_{0.4} \mathrm{Sr}_{0.6} \mathrm{Fe}_{y} \mathrm{Mn}_{1-y} \mathrm{O}_{3-\delta}$ catalysts. Miyakoshi et al. investigated the catalytic performance of partially Mn-substituted $\mathrm{Fe}-\mathrm{K}$ catalysts (Miyakoshi et al., 2001). They reported that styrene selectivity was almost invariable in whole range of Mn-substitution. In this work, styrene selectivity over $\mathrm{Ba}_{0.4} \mathrm{Sr}_{0.6} \mathrm{Fe}_{y} \mathrm{Mn}_{1-y} \mathrm{O}_{3-\delta}$
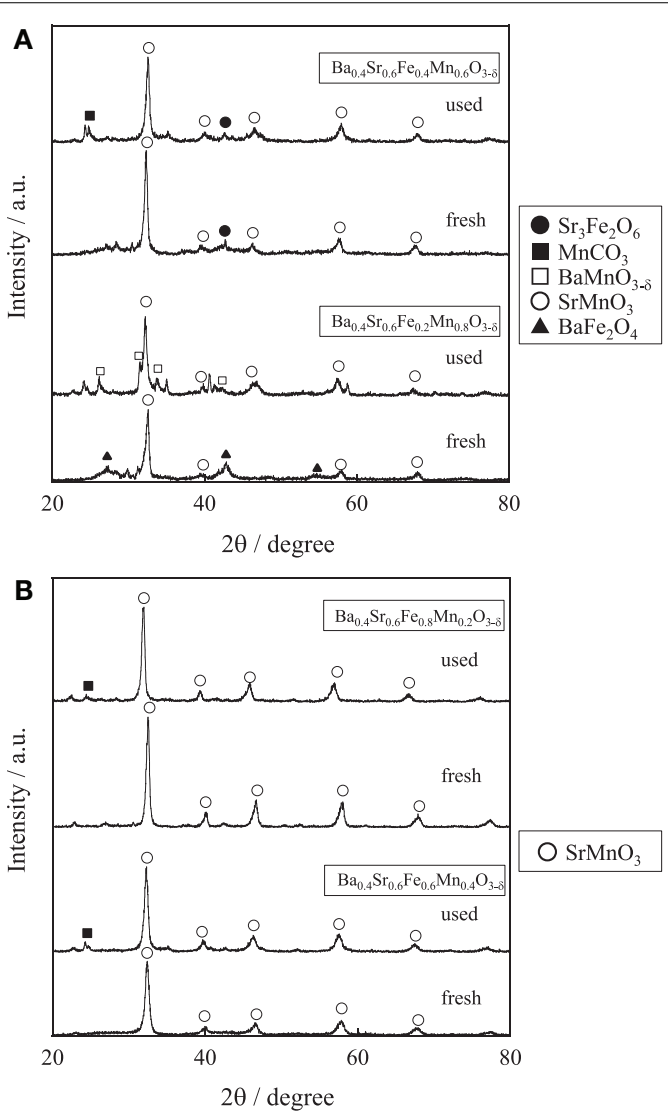

FIGURE 4 | XRD patterns for (A) $\mathrm{Ba}_{0.4} \mathrm{Sr}_{0.6} \mathrm{Fe}_{y} \mathrm{Mn}_{1-y} \mathrm{O}_{3-\delta}(y=0.2$ and $0.4)$ catalysts and $(B) \mathrm{Ba}_{0.4} \mathrm{Sr}_{0.6} \mathrm{Fe}_{y} \mathrm{Mn}_{1-y} \mathrm{O}_{3-\delta}(y=0.6$ and 0.8$)$ catalysts.
$(0.2 \leq y \leq 0.8)$ catalyst was also invariable within the range: $0.2 \leq y \leq 0.6$ as shown in Table 5. The trend was almost the same. The reason for low styrene selectivity over the $\mathrm{Ba}_{0.4} \mathrm{Sr}_{0.6} \mathrm{Fe}_{0.8} \mathrm{Mn}_{0.2} \mathrm{O}_{3-\delta}$ catalyst was significantly low styrene yield, compared with $\mathrm{Ba}_{0.4} \mathrm{Sr}_{0.6} \mathrm{Fe}_{y} \mathrm{Mn}_{1-y} \mathrm{O}_{3-\delta}(0.2 \leq y \leq 0.6)$ catalysts. Low activity might be derived from low mixed conductivity of the catalyst.

Among these catalysts, $\mathrm{Ba}_{0.4} \mathrm{Sr}_{0.6} \mathrm{Fe}_{0.6} \mathrm{Mn}_{0.4} \mathrm{O}_{3-\delta}$ catalyst showed superior catalytic performance. Comparing the activity and selectivity to styrene on $\mathrm{Ba}_{0.4} \mathrm{Sr}_{0.6} \mathrm{Fe}_{0.6} \mathrm{Mn}_{0.4} \mathrm{O}_{3}-\delta$ catalyst with that on $\mathrm{Fe}-\mathrm{K}$ industrial catalyst, $\mathrm{Ba}_{0.4} \mathrm{Sr}_{0.6} \mathrm{Fe}_{0.6} \mathrm{Mn}_{0.4} \mathrm{O}_{3-\delta}$ catalyst revealed higher initial activity and almost identical selectivity, as shown in Figure 3 and Table 5.

\section{CHARACTERIZATION OF SURFACE ANALYSES OF $\mathrm{Ba}_{0.4} \mathrm{Sr}_{0.6} \mathrm{Fe}_{0.6} \mathrm{Mn}_{0.4} \mathrm{O}_{3-\delta}$ CATALYST BY X-RAY PHOTOELECTRON SPECTROSCOPY MEASUREMENT FOR CHARACTERIZATION OF CATALYST SURFACE}

XPS measurement was carried out to evaluate the concentration of lattice vacancy in the $\mathrm{Ba}_{0.4} \mathrm{Sr}_{0.6} \mathrm{Fe}_{0.6} \mathrm{Mn}_{0.4} \mathrm{O}_{3}-\delta$ catalyst as-made catalyst and during $\mathrm{EBDH}$ reaction, and to investigate the oxidation state of B-site cation in the catalyst. XPS spectra of $\mathrm{Mn} 2 \mathrm{p}$ and Fe2p are shown in Figure 5. Table 6 shows binding energies of $\mathrm{Mn}_{2} \mathrm{p}_{3 / 2}(\mathrm{Mn} 2 \mathrm{p})$ and $\mathrm{Fe} 2 \mathrm{p}_{3 / 2}(\mathrm{Fe} 2 \mathrm{p})$ core-levels of as-made catalyst, the catalyst after $10 \mathrm{~min}$ reaction and the catalyst after $2 \mathrm{~h}$ reaction. The concentration of oxygen vacancy at the surface calculated from the surface atomic ratio is shown in Table 6. Here, the peak percentage of components is in parenthesis. As for as-made catalyst, the peak of Mn2p included two components at 641.94 and $640.98 \mathrm{eV}$. Former and latter peaks were attributed to $\mathrm{Mn}^{4+}$ and $\mathrm{Mn}^{3+}$, respectively (Carver et al., 1972; Oku and Hirokawa, 1976; Ponce et al., 2000). The peak of Fe2p included components at 711.71 and $709.56 \mathrm{eV}$ which were attributed to $\mathrm{Fe}^{4+}$ and $\mathrm{Fe}^{3+}$, respectively (Ghaffari et al., 2012). The peak percentage of components was as follows; $\mathrm{Mn}^{4+}: 51.5 \%$, $\mathrm{Mn}^{3+}: 48.5 \%, \mathrm{Fe}^{4+}: 30.3 \%$, and $\mathrm{Fe}^{3+}: 69.7 \%$. The concentration of oxygen vacancy; $3-\delta$ was 2.88 . The composition of perovskite which has no lattice vacancy, is $\mathrm{ABO}_{3}$, in other words $\mathrm{d}$ is 0 . In this work, the low valence cation; $\mathrm{Ba}$ was doped in A-site of

Table 5 | Selectivity to styrene, benzene, and toluene on EBDH over $\mathrm{Ba}_{0.4} \mathrm{Sr}_{0.6} \mathrm{Fe}_{y} \mathrm{Mn}_{1-y} \mathrm{O}_{3-\delta}(0.2 \leq x \leq 0.8)$ and $\mathrm{Fe}-\mathrm{K}$ catalyst.

\begin{tabular}{|c|c|c|c|c|c|c|c|}
\hline \multirow[t]{2}{*}{ Catalyst } & \multirow{2}{*}{$\begin{array}{l}\text { BET specific } \\
\text { surface } \\
\text { area } / \mathbf{m}^{2} \mathbf{g}^{-1}\end{array}$} & \multicolumn{3}{|c|}{$\begin{array}{c}\text { Selectivity } \\
(0.5 \mathrm{~h}) / \%\end{array}$} & \multicolumn{3}{|c|}{$\begin{array}{c}\text { Selectivity } \\
(2 \mathrm{~h}) / \%\end{array}$} \\
\hline & & Sty & $\mathrm{Bz}$ & Tol & Sty & $\mathrm{Bz}$ & Tol \\
\hline $\begin{array}{l}\mathrm{Ba}_{0.4} \mathrm{Sr}_{0.6} \mathrm{Fe}_{0.2} \\
\mathrm{Mn}_{0.8} \mathrm{O}_{3-8}\end{array}$ & 8.9 & 95.9 & 2.1 & 2.0 & 98.2 & 0.3 & 1.5 \\
\hline $\begin{array}{l}\mathrm{Ba}_{0.4} \mathrm{Sr}_{0.6} \mathrm{Fe}_{0.4} \\
\mathrm{Mn}_{0.6} \mathrm{O}_{3-\delta}\end{array}$ & 9.0 & 96.1 & 2.4 & 1.5 & 98.0 & 0.4 & 1.6 \\
\hline $\begin{array}{l}\mathrm{Ba}_{0.4} \mathrm{Sr}_{0.6} \mathrm{Fe}_{0.6} \\
\mathrm{Mn}_{0.4} \mathrm{O}_{3-\delta}\end{array}$ & 10.1 & 96.6 & 1.7 & 1.7 & 97.8 & 0.6 & 1.6 \\
\hline $\begin{array}{l}\mathrm{Ba}_{0.4} \mathrm{Sr}_{0.6} \mathrm{Fe}_{0.8} \\
\mathrm{Mn}_{0.2} \mathrm{O}_{3-\delta}\end{array}$ & 5.7 & 89.7 & 8.2 & 2.2 & 92.4 & 4.7 & 2.9 \\
\hline $\mathrm{Fe}-\mathrm{K}$ & 2.0 & 97.8 & 1.1 & 1.1 & 98.3 & 0.9 & 0.8 \\
\hline
\end{tabular}


perovskite-type oxides, in order to maintain the electrical neutrality, the electrical charge unbalance could be compensated via following ways: (a) the increase of valence state of B-site metal cation and (b) the production of lattice vacancy in the structure. Therefore, the result indicated the presence of lattice vacancy.

As for the $\mathrm{Ba}_{0.4} \mathrm{Sr}_{0.6} \mathrm{Fe}_{0.6} \mathrm{Mn}_{0.4} \mathrm{O}_{3}-\delta$ catalyst after 10 min reaction, the peak of $\mathrm{Mn} 2 \mathrm{p}$ was 642.25 and $640.86 \mathrm{eV}$. These values were attributed to the $\mathrm{Mn}^{4+}, \mathrm{Mn}^{3+}$, respectively in Figure 5B. The $\mathrm{Fe} 2 \mathrm{p}$ peak can be divided into two peaks, namely $\mathrm{Fe}^{4+}$ at $711.59 \mathrm{eV}$ and $\mathrm{Fe}^{3+}$ at $709.49 \mathrm{eV}$. The peak percentage of components was as follows; $\mathrm{Mn}^{4+}: 36.4 \%, \mathrm{Mn}^{3+}: 63.6 \%, \mathrm{Fe}^{4+}: 29.5 \%$, and $\mathrm{Fe}^{3+}: 70.5 \%$. The $\mathrm{Ba}_{0.4} \mathrm{Sr}_{0.6} \mathrm{Fe}_{0.6} \mathrm{Mn}_{0.4} \mathrm{O}_{3-\delta}$ catalyst was reduced by $\mathrm{EB}$ and high valence cation of $\mathrm{Mn}^{4+}$ was reduced to lower valence cation of $\mathrm{Mn}^{3+}$. While, the oxidation state of Fe did not almost change after the reaction. In fact, the Fe cation in the $\mathrm{Ba}_{0.4} \mathrm{Sr}_{0.6} \mathrm{Fe}_{0.6} \mathrm{Mn}_{0.4} \mathrm{O}_{3-\delta}$ catalyst was not reduced by $\mathrm{EB}$. The concentration of oxygen vacancy; $3-\delta$ was 2.83 . The catalyst also had lattice vacancy in the perovskite structure. While, the peak

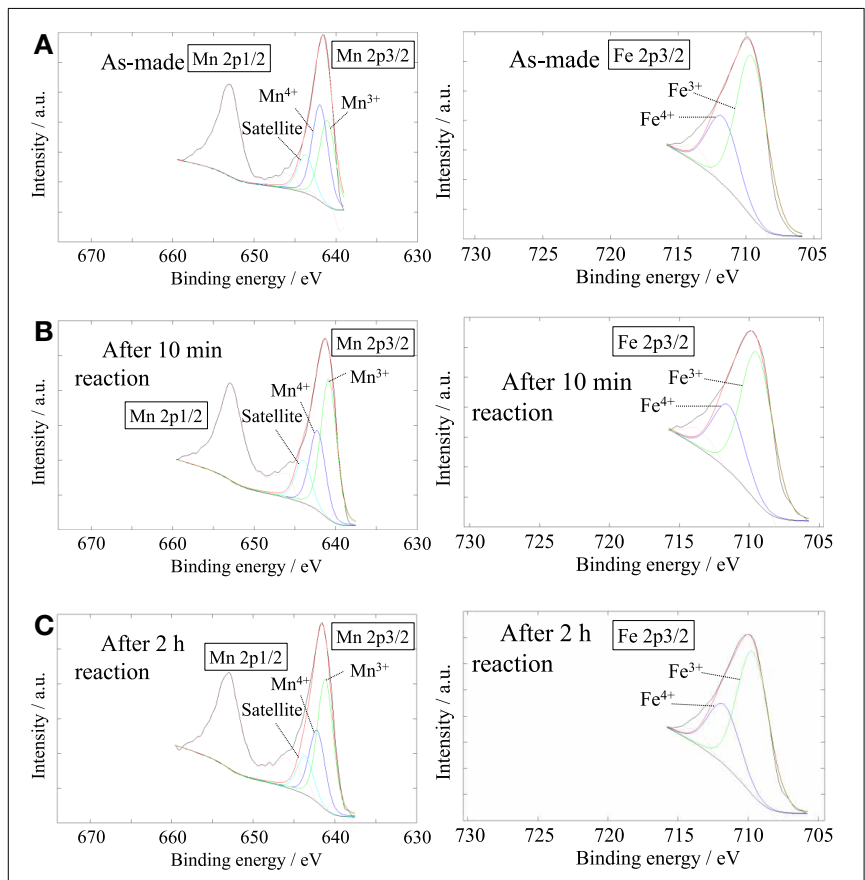

FIGURE 5 | XPS spectra of Mn2p (left) and Fe 2p3/2 (right) for $\mathrm{Ba}_{0.4}$ $\mathrm{Sr}_{0.6} \mathrm{Fe}_{0.6} \mathrm{Mn}_{0.4} \mathrm{O}_{3-\delta} ;(\mathrm{A})$ as-made, (B) after $10 \mathrm{~min}$ of reaction, (C) after $2 \mathrm{~h}$ of reaction. of $\mathrm{Mn} 2 \mathrm{p}$ and $\mathrm{Fe} 2 \mathrm{p}$ in the $\mathrm{Ba}_{0.4} \mathrm{Sr}_{0.6} \mathrm{Fe}_{0.6} \mathrm{Mn}_{0.4} \mathrm{O}_{3-\delta}$ catalyst after $2 \mathrm{~h}$ reaction contained $\mathrm{Mn}^{4+}, \mathrm{Mn}^{3+}, \mathrm{Fe}^{4+}$, and $\mathrm{Fe}^{3+}$. The mixed valence of $\mathrm{Mn}$ and $\mathrm{Fe}$ was not almost changed, compared with the catalyst after $10 \mathrm{~min}$ reaction. The peak percentage of components was as follows; $\mathrm{Mn}^{4+}: 35.9 \%, \mathrm{Mn}^{3+}: 64.1 \%, \mathrm{Fe}^{4+}: 30.3 \%$, and $\mathrm{Fe}^{3+}: 69.7 \%$.

We considered the role of Fe from the results of XPS results. Preliminarily studies showed that redox-type mechanism proceeded on the catalyst; (Equation 2) oxidative dehydrogenation of ethylbenzene using lattice oxygen and (Equation 3) regenerating lattice vacancy by $\mathrm{H}_{2} \mathrm{O}$ (Watanabe et al., 2011, 2013). In this work, Mn-based catalyst showed high initial activity, but low stability. While, stability of the catalyst was improved by Fe substitution of $\mathrm{Ba}_{0.4} \mathrm{Sr}_{0.6} \mathrm{Fe}_{y} \mathrm{Mn}_{1-y} \mathrm{O}_{3-\delta}$ catalyst. Therefore, we proposed that the role of Mn and Fe might be the site for releasing lattice oxygen and the site for regenerating lattice vacancy, respectively. The oxidation state of $\mathrm{Fe}$ and $\mathrm{Mn}$ on $\mathrm{Ba}_{0.4} \mathrm{Sr}_{0.6} \mathrm{Fe}_{0.6} \mathrm{Mn}_{0.4} \mathrm{O}_{3}-\delta$ catalyst was $\mathrm{Mn}^{4+} / \mathrm{Mn}^{3+}$ and $\mathrm{Fe}^{4+} / \mathrm{Fe}^{3+}$, respectively. So, the aromatic ring of $\mathrm{EB}$ was adsorbed onto $\mathrm{Mn}^{4+}$. Then, styrene and $\mathrm{H}_{2} \mathrm{O}$ were produced via oxidative dehydrogenation of ethylbenzene, following that $\mathrm{Mn}^{4+}$ and $\mathrm{Fe}^{4+}$ were reduced to $\mathrm{Mn}^{3+}$ and $\mathrm{Fe}^{3+}$. $\mathrm{Co}$-feeding steam was adsorbed on reduced $\mathrm{Fe}^{3+}$ site. Lattice oxygen was regenerated by oxidation of $\mathrm{Fe}^{3+}$ to $\mathrm{Fe}^{4+}$ and of $\mathrm{Mn}^{3+}$ to $\mathrm{Mn}^{4+}$. Summarily, the role of Fe was considered to be the promotion of regenerating lattice oxygen derived from high redox property of $\mathrm{Fe}^{4+} / \mathrm{Fe}^{3+}$.

\section{DEHYDROGENATION ACTIVITY AND ROBUSTNESS OF $\mathrm{Ba}_{0.4} \mathrm{Sr}_{0.6} \mathrm{Fe}_{0.6} \mathrm{Mn}_{0.4} \mathrm{O}_{3-\delta}$ CATALYST UNDER LOW-TEMPERATURE OR LOW STEAM/EB CONDITION}

To examine the dehydrogenation activity and robustness of the $\mathrm{Ba}_{0.4} \mathrm{Sr}_{0.6} \mathrm{Fe}_{0.6} \mathrm{Mn}_{0.4} \mathrm{O}_{3-\delta}$ catalyst under low temperature or low steam/EB condition, catalytic activity tests were conducted. The Fe-K oxide catalyst was used as the control. Figure 6A presents results for activity tests at $783 \mathrm{~K}$ (i.e., lower temperature) under steam/EB of 12 . The styrene yield of the $\mathrm{Ba}_{0.4} \mathrm{Sr}_{0.6} \mathrm{Fe}_{0.6} \mathrm{Mn}_{0.4} \mathrm{O}_{3-\delta}$ catalyst was $16.3 \%$ and that of the $\mathrm{Fe}-$ $\mathrm{K}$ catalyst was $10.4 \%$ at $30 \mathrm{~min}$. The initial activity of the $\mathrm{Ba}_{0.4} \mathrm{Sr}_{0.6} \mathrm{Fe}_{0.6} \mathrm{Mn}_{0.4} \mathrm{O}_{3-\delta}$ catalyst was 1.57 times higher than that of the $\mathrm{Fe}-\mathrm{K}$ oxide catalyst at such a low temperature.

Next, the robustness of the $\mathrm{Ba}_{0.4} \mathrm{Sr}_{0.6} \mathrm{Fe}_{0.6} \mathrm{Mn}_{0.4} \mathrm{O}_{3-\delta}$ catalyst for low steam/EB operation was examined, and catalytic activity tests were performed at $813 \mathrm{~K}$ with steam/EB molar ratio of 2. Figure 6B presents results for the activity test over the $\mathrm{Ba}_{0.4} \mathrm{Sr}_{0.6} \mathrm{Fe}_{0.6} \mathrm{Mn}_{0.4} \mathrm{O}_{3-\delta}$ and the $\mathrm{Fe}-\mathrm{K}$ catalysts under the condition of steam/EB molar ratio of 2. From Figure $6 \mathrm{~B}$, the

Table 6 | Binding energy and surface lattice vacancy of $\mathrm{Ba}_{0.4} \mathrm{Sr}_{0.6} \mathrm{Fe}_{0.6} \mathrm{Mn}_{0.4} \mathrm{O}_{3-\delta}$ catalyst under various reaction conditions.

\begin{tabular}{|c|c|c|c|c|c|}
\hline Condition & \multicolumn{2}{|c|}{ Mn2p/eV } & \multicolumn{2}{|c|}{$\mathrm{Fe} 2 \mathrm{p} / \mathrm{eV}$} & Surface composition \\
\hline After 10 min reaction & $642.25(36.4)$ & $640.86(63.6)$ & $711.59(29.5)$ & $709.49(70.5)$ & $\mathrm{Ba}_{0.69} \mathrm{Sr}_{0.47} \mathrm{Fe}_{0.54} \mathrm{Mn}_{0.47} \mathrm{O}_{2.83}$ \\
\hline After $2 \mathrm{~h}$ reaction & 642.19 (35.9) & $641.17(64.1)$ & $711.71(30.3)$ & $709.68(69.7)$ & $\mathrm{Ba}_{0.81} \mathrm{Sr}_{0.20} \mathrm{Fe}_{0.63} \mathrm{Mn}_{0.51} \mathrm{O}_{2.87}$ \\
\hline
\end{tabular}

Peak percentage of components is in parenthesis. 
$\mathrm{Ba}_{0.4} \mathrm{Sr}_{0.6} \mathrm{Fe}_{0.6} \mathrm{Mn}_{0.4} \mathrm{O}_{3-\delta}$ catalyst showed high robustness under low steam conditions. However, the activity of Fe-K oxide catalyst gradually decreased with time on stream. These results might be derived from the superior ability for steam activation over the $\mathrm{Ba}_{0.4} \mathrm{Sr}_{0.6} \mathrm{Fe}_{0.6} \mathrm{Mn}_{0.4} \mathrm{O}_{3-\delta}$ catalyst compared to that of the $\mathrm{Fe}-\mathrm{K}$ catalyst. For the Fe-K catalyst, low steam/EB conditions caused a low regeneration rate of lattice oxygen, and deactivation was observed.

The reason for the higher activity of the $\mathrm{Ba}_{0.4} \mathrm{Sr}_{0.6} \mathrm{Fe}_{0.6} \mathrm{Mn}_{0.4}$ $\mathrm{O}_{3}-\delta$ was investigated in terms of the redox property of the catalyst. An isotope exchange reaction from ${ }^{16} \mathrm{O}_{\text {lat }}$ to ${ }^{18} \mathrm{O}_{\text {lat }}$ in the catalyst by switching $\mathrm{H}_{2}^{16} \mathrm{O}$ flow to $\mathrm{H}_{2}^{18} \mathrm{O}$ at $783 \mathrm{~K}$ was conducted over the $\mathrm{Ba}_{0.4} \mathrm{Sr}_{0.6} \mathrm{Fe}_{0.6} \mathrm{Mn}_{0.4} \mathrm{O}_{3-\delta}$ catalyst. We have already found that $\mathrm{Fe}-\mathrm{K}$ catalyst works on a redox mechanism during EBDH (Sekine et al., 2008). Figure 7 presents temporary profiles of the flow rate of $\mathrm{H}_{2}^{18} \mathrm{O}$ by the time that the stable flow rate of $\mathrm{H}_{2}^{18} \mathrm{O}$ was confirmed. Here, time " 0 " was the starting time at which $\mathrm{H}_{2}^{18} \mathrm{O}(30 \%)$ and $\mathrm{H}_{2}^{16} \mathrm{O}(70 \%)$ were supplied
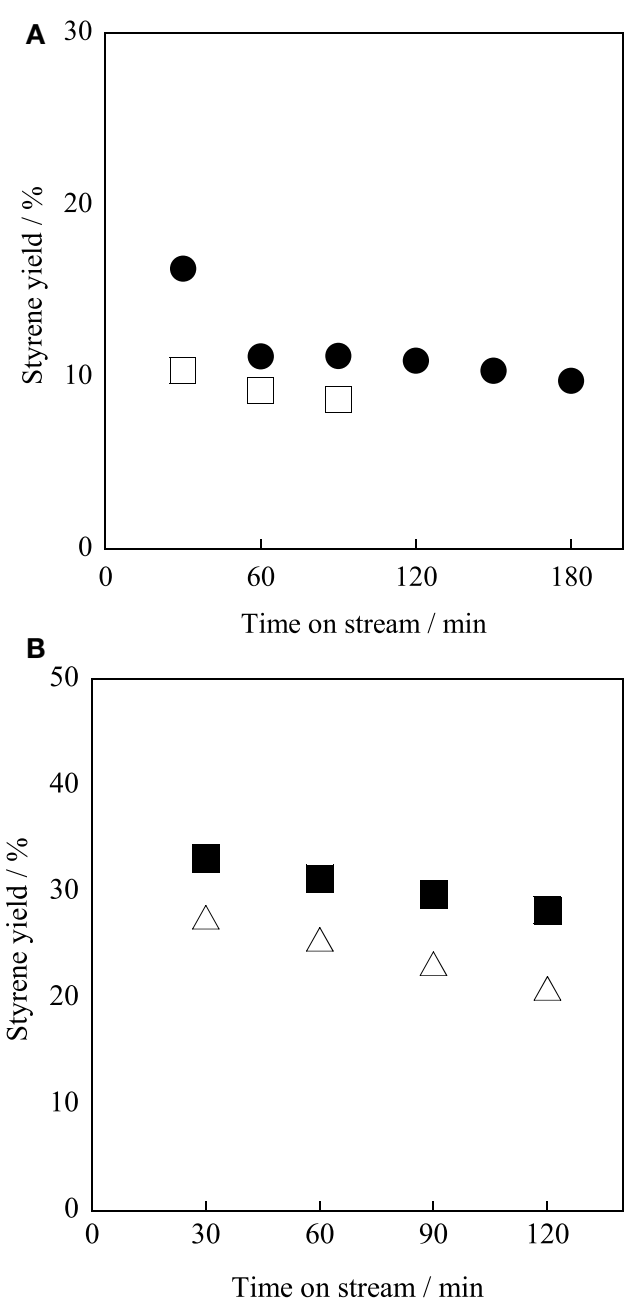

FIGURE 6 | Catalytic activity tests over (filled symbols) $\mathrm{Ba}_{0.4} \mathrm{Sr}_{0.6}$ $\mathrm{Fe}_{0.6} \mathrm{Mn}_{0.4} \mathrm{O}_{3-\delta}$ and (open symbols) Fe-K catalysts (A) at $783 \mathrm{~K}$ and under steam/EB molar ratio of 12, (B) at $813 \mathrm{~K}$ under steam/EB molar ratio of 2. to the catalyst. $\mathrm{H}_{2}^{18} \mathrm{O}$ was monitored sooner after the feeding of $\mathrm{H}_{2}^{18} \mathrm{O}$ on a blank test and over $\alpha-\mathrm{Al}_{2} \mathrm{O}_{3}$ as a non-redox control, respectively. The isotope exchange reaction did not proceed over $\alpha-\mathrm{Al}_{2} \mathrm{O}_{3}$, in accordance with the profile of the blank test. Different from $\alpha-\mathrm{Al}_{2} \mathrm{O}_{3}$, a slow exchange profile was observed over $\mathrm{Ba}_{0.4} \mathrm{Sr}_{0.6} \mathrm{Fe}_{0.6} \mathrm{Mn}_{0.4} \mathrm{O}_{3-\delta}$ catalyst and the isotope exchange continued for about $10 \mathrm{~min}$ from the switching gas. This phenomenon shows that an exchange reaction (Equation 7) proceeds only on $\mathrm{Ba}_{0.4} \mathrm{Sr}_{0.6} \mathrm{Fe}_{0.6} \mathrm{Mn}_{0.4} \mathrm{O}_{3-\delta}$ catalyst.

$$
\mathrm{H}_{2}^{18} \mathrm{O}+{ }^{16} \mathrm{O}_{\text {lat }}^{2-} \leftrightarrow \mathrm{H}_{2}^{16} \mathrm{O}+{ }^{18} \mathrm{O}_{\text {lat }}^{2-}
$$

Here, ${ }^{16} \mathrm{O}_{\text {lat }}^{2-}$ and ${ }^{18} \mathrm{O}_{\text {lat }}^{2-}$ denotes lattice oxygen with a mass number of 16 and 18. Then amounts of exchanged lattice oxygen were calculated. The amount was large compared with the amount of surface lattice oxygen. Bulk lattice oxygen was exchanged according to the following equation (Equations 8 and 9).

$$
\begin{array}{r}
\mathrm{H}_{2}^{18} \mathrm{O}+{ }^{16} \mathrm{O}_{\text {lat, surf }}^{2-} \leftrightarrow \mathrm{H}_{2}^{16} \mathrm{O}+{ }^{18} \mathrm{O}_{\text {lat, surf }}^{2-} \\
{ }^{18} \mathrm{O}_{\text {lat, surf }}^{2-}+\mathrm{V}_{\text {ox, bulk }} \leftrightarrow{ }^{16} \mathrm{O}_{\text {lat, bulk }}^{2-}+\mathrm{V}_{\text {ox, surf }}
\end{array}
$$

Here, "surf" and "bulk" respectively signify the surface and bulk of the catalyst. The surface exchange reaction proceeded on the catalyst, and then the surface lattice oxygen diffused to bulk with redox of the catalyst. Figure 8 shows the result of $\mathrm{H}_{2}$-temperature programmed reduction (TPR) measurement of $\mathrm{Ba}_{0.4} \mathrm{Sr}_{0.6} \mathrm{Fe}_{y} \mathrm{Mn}_{1-y} \mathrm{O}_{3-\delta}(y=0.2,0.6,0.8)$ catalysts. The weight loss of the catalyst was measured by heating to 1173 $\mathrm{K}\left(10 \mathrm{~K} \mathrm{~min}^{-1}\right)$ under $10 \mathrm{vol} \% \mathrm{H}_{2}$ atmosphere. The start of the reduction was considered to reflect the consumption of lattice oxygen on the vicinity of the surface. From this Figure, $\mathrm{Ba}_{0.4} \mathrm{Sr}_{0.6} \mathrm{Fe}_{0.8} \mathrm{Mn}_{0.2} \mathrm{O}_{3-\delta}$ catalyst was less likely to be reduced. Namely, reducibility of the catalyst was low, comparing with other catalysts. Low releasing ability of lattice oxygen might cause low activity for dehydrogenation of ethylbenzene. Based

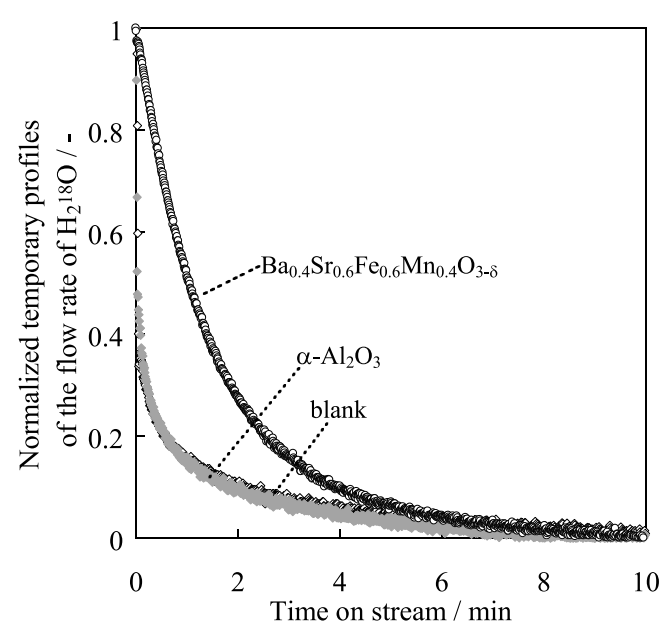

FIGURE 7 | Normalized temporary profile of $\mathrm{H}_{2}^{18} \mathrm{O}$ flow rate over $\alpha-\mathrm{Al}_{2} \mathrm{O}_{3}$ or $\mathrm{Ba}_{0.4} \mathrm{Sr}_{0.6} \mathrm{Fe}_{0.6} \mathrm{Mn}_{0.4} \mathrm{O}_{3-\delta}$ catalyst. 
on these results, the $\mathrm{Ba}_{0.4} \mathrm{Sr}_{0.6} \mathrm{Fe}_{0.6} \mathrm{Mn}_{0.4} \mathrm{O}_{3-\delta}$ catalyst enabled redox at low temperature of $783 \mathrm{~K}$. Consequently, high activity is apparently derived from high redox property of the $\mathrm{Ba}_{0.4} \mathrm{Sr}_{0.6} \mathrm{Fe}_{0.6} \mathrm{Mn}_{0.4} \mathrm{O}_{3-\delta}$ catalyst.

For elucidating the greater robustness of the $\mathrm{Ba}_{0.4} \mathrm{Sr}_{0.6} \mathrm{Fe}_{0.6}$ $\mathrm{Mn}_{0.4} \mathrm{O}_{3}-\delta$ catalyst than that of the $\mathrm{Fe}-\mathrm{K}$ catalyst, redox properties of the $\mathrm{Ba}_{0.4} \mathrm{Sr}_{0.6} \mathrm{Fe}_{0.6} \mathrm{Mn}_{0.4} \mathrm{O}_{3-\delta}$ and the $\mathrm{Fe}-\mathrm{K}$ catalysts were examined using thermogravimetric measurement under $\mathrm{H}_{2}$ atmosphere and $\mathrm{H}_{2} / \mathrm{H}_{2} \mathrm{O}$ atmosphere. Figure 9A portrays the thermogravimetric profile of the $\mathrm{Ba}_{0.4} \mathrm{Sr}_{0.6} \mathrm{Fe}_{0.6} \mathrm{Mn}_{0.4} \mathrm{O}_{3-\delta}$ catalyst under various partial pressures at $783 \mathrm{~K}$ and Figure 9B shows that of the $\mathrm{Fe}-\mathrm{K}$ catalyst under the same condition. From Figure 9A, 3.1 wt $\%$ of the $\mathrm{Ba}_{0.4} \mathrm{Sr}_{0.6} \mathrm{Fe}_{0.6} \mathrm{Mn}_{0.4} \mathrm{O}_{3}-\delta$ catalyst was reduced under $10 \mathrm{vol} \% \mathrm{H}_{2} / \mathrm{N}_{2}$ atmosphere. The reduced amount was equivalent to $405 \mathrm{mmol}$ mol-cat ${ }^{-1}$, which was $13.5 \%$ of lattice oxygen in perovskite-type oxide. However, $2.5 \mathrm{wt} \%$ of the $\mathrm{Ba}_{0.4} \mathrm{Sr}_{0.6} \mathrm{Fe}_{0.6} \mathrm{Mn}_{0.4} \mathrm{O}_{3}-\delta$ was reduced under $10 \mathrm{vol} \% \mathrm{H}_{2}$ and 1 vol $\% \mathrm{H}_{2} \mathrm{O}$. The value corresponded to $330 \mathrm{mmol} \mathrm{mol-cat}^{-1}$ of lattice oxygen, which was $11 \%$ of lattice oxygen in perovskite-type oxide. Further increase of the partial pressure of steam decreased the value to $308 \mathrm{mmol} \mathrm{mol-cat}^{-1}$ under $10 \mathrm{vol} \% \mathrm{H}_{2}$ and $2.5 \mathrm{vol} \%$ $\mathrm{H}_{2} \mathrm{O}$. The lattice oxygen of $10.3 \%$ was released under this condition. Figure 9B showed that the $\mathrm{Fe}-\mathrm{K}$ was reduced to $\mathrm{Fe}$ metal under 10 vol $\% \mathrm{H}_{2} / \mathrm{N}_{2}$ atmosphere. Also, the $\mathrm{Fe}-\mathrm{K}$ was reduced to Fe metal under $10 \mathrm{vol} \% \mathrm{H}_{2}$ and 1.0 vol $\% \mathrm{H}_{2} \mathrm{O}$. Compared with the case in the absence of $\mathrm{H}_{2} \mathrm{O}\left(10 \mathrm{vol} \% \mathrm{H}_{2} / \mathrm{N}_{2}\right)$, the reduction rate was suppressed by $\mathrm{H}_{2} \mathrm{O}$. Even if the partial pressure of steam further increased, the $\mathrm{Fe}-\mathrm{K}$ was reduced to $\mathrm{Fe}_{3} \mathrm{O}_{4}$ and additional reduction gradually proceeded from $\mathrm{Fe}_{3} \mathrm{O}_{4}$ to $\mathrm{Fe}$ metal with reaction time under 10 vol $\% \mathrm{H}_{2}$ and 2.5 vol $\% \mathrm{H}_{2} \mathrm{O}$ condition. The nature of the structural stability of the $\mathrm{Fe}-\mathrm{K}$ catalyst was low in reducing atmosphere. From these results, coexisting $\mathrm{H}_{2} \mathrm{O}$ in the atmosphere affected the reduction behavior of the $\mathrm{Ba}_{0.4} \mathrm{Sr}_{0.6} \mathrm{Fe}_{0.6} \mathrm{Mn}_{0.4} \mathrm{O}_{3-\delta}$ : i.e., reduction was suppressed by $\mathrm{H}_{2} \mathrm{O}$ compared to the case in the absence of $\mathrm{H}_{2} \mathrm{O}$. We confirmed that the regeneration of consumed lattice oxygen by $\mathrm{H}_{2} \mathrm{O}$

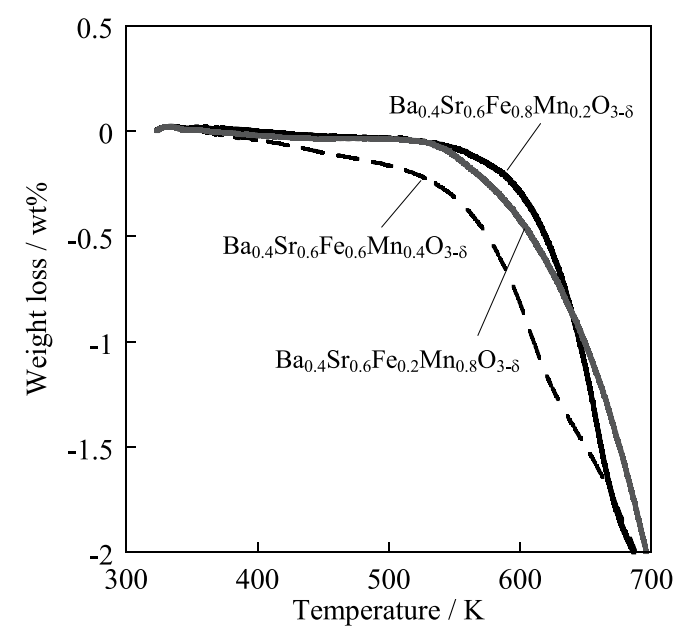

FIGURE 8 | Reduction behavior of $\mathrm{Ba}_{0.4} \mathrm{Sr}_{0.6} \mathrm{Fe}_{y} \mathrm{Mn}_{1-y} \mathrm{O}_{3-\delta}(y=0.2$, $0.6,0.8)$ catalysts under $10 \mathrm{vol} \% \mathrm{H}_{2}$ atmosphere. proceeded on the catalyst in our previous study (Watanabe et al., 2011). Therefore, the suppression of the reduction was derived from the increased regeneration rate of the consumed lattice oxygen in perovskite oxide by $\mathrm{H}_{2} \mathrm{O}$. These results showed that the $\mathrm{Ba}_{0.4} \mathrm{Sr}_{0.6} \mathrm{Fe}_{0.6} \mathrm{Mn}_{0.4} \mathrm{O}_{3-\delta}$ catalyst revealed high robustness under a reductive atmosphere and activated $\mathrm{H}_{2} \mathrm{O}$ more easily than the $\mathrm{Fe}-\mathrm{K}$ catalyst.

For low reaction temperature and low steam/EB reaction conditions, the $\mathrm{Ba}_{0.4} \mathrm{Sr}_{0.6} \mathrm{Fe}_{0.6} \mathrm{Mn}_{0.4} \mathrm{O}_{3-\delta}$ catalyst had high activity and robustness. Results show that the $\mathrm{Ba}_{0.4} \mathrm{Sr}_{0.6} \mathrm{Fe}_{0.6} \mathrm{Mn}_{0.4} \mathrm{O}_{3-\delta}$ is a promising catalyst for industrial dehydrogenation processes.

\section{CONCLUSION}

For EBDH, the substitution of $\mathrm{Ba}^{2+}$ for $\mathrm{Sr}^{2+}$ over $\mathrm{Ba}_{1-x} \mathrm{Sr}_{\mathrm{x}} \mathrm{Fe}_{y} \mathrm{Mn}_{1-y} \mathrm{O}_{3-\delta}(x=0,0.2,0.4,0.6,0.8$, and $1, y=0$, $0.2,0.4,0.6$, and 0.8 ) catalysts enhanced the initial activity for $\mathrm{EBDH}$, but activity decreased with time on stream. Optimization of B-site substitution ratio of $\mathrm{Fe}$ in $\mathrm{Ba}_{0.4} \mathrm{Sr}_{0.6} \mathrm{Fe}_{y} \mathrm{Mn}_{1-y} \mathrm{O}_{3-\delta}$ catalyst was conducted, and results showed that the stability

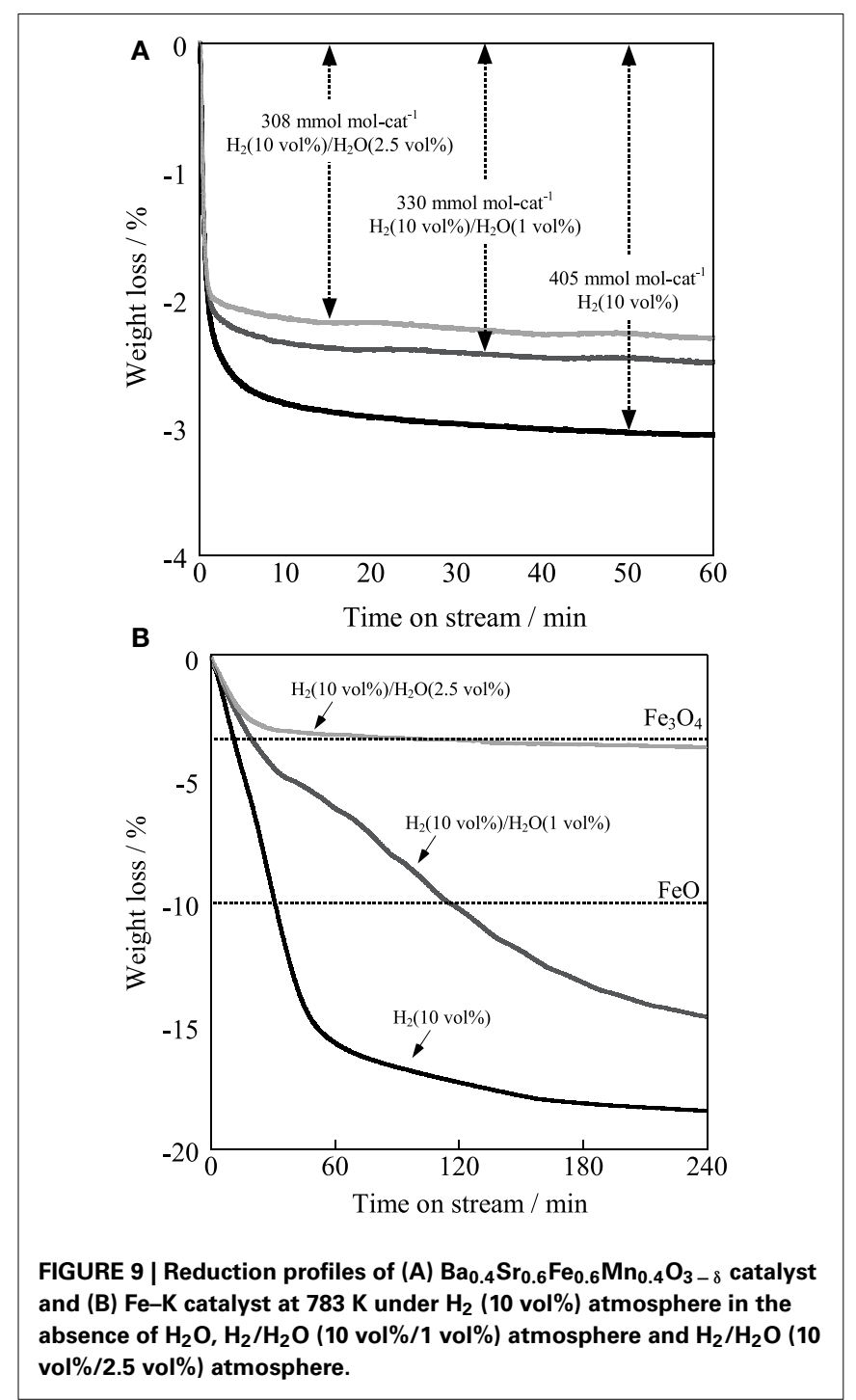


for $\mathrm{EBDH}$ was improved by an increase of Fe substitution ratio. Optimized $\mathrm{Ba}_{0.4} \mathrm{Sr}_{0.6} \mathrm{Fe}_{0.6} \mathrm{Mn}_{0.4} \mathrm{O}_{3-\delta}$ catalyst showed high styrene yield of $29.2 \%$ and selectivity to styrene of $96.6 \%$ at $813 \mathrm{~K}$. The dehydrogenation activity and robustness of $\mathrm{Ba}_{0.4} \mathrm{Sr}_{0.6} \mathrm{Fe}_{0.6} \mathrm{Mn}_{0.4} \mathrm{O}_{3-\delta}$ catalyst were investigated under low-temperature and low steam/EB reaction conditions. Consequently, the catalyst of $\mathrm{Ba}_{0.4} \mathrm{Sr}_{0.6} \mathrm{Fe}_{0.6} \mathrm{Mn}_{0.4} \mathrm{O}_{3-\delta}$ revealed high activity and superior robustness under these severe conditions derived from high redox property of the catalyst. From the evaluation of redox property of the $\mathrm{Ba}_{0.4} \mathrm{Sr}_{0.6} \mathrm{Fe}_{0.6} \mathrm{Mn}_{0.4} \mathrm{O}_{3}-\delta$ catalyst, thermogravimetric profile was measured under $\mathrm{H}_{2} / \mathrm{H}_{2} \mathrm{O}$ atmosphere at $783 \mathrm{~K}$. The result showed that reduction was suppressed by the presence of $\mathrm{H}_{2} \mathrm{O}$, implied that the lattice oxygen in perovskite-structure was consumed by $\mathrm{H}_{2}$, subsequently the consumed lattice oxygen was regenerated by $\mathrm{H}_{2} \mathrm{O}$. Additional support for this result was confirmed by $\mathrm{H}_{2} \mathrm{O}$ surface exchange reaction. The lattice oxygen was exchanged with steam by redox of the catalyst at low temperature of $783 \mathrm{~K}$.

Therefore, $\mathrm{Ba}_{0.4} \mathrm{Sr}_{0.6} \mathrm{Fe}_{0.6} \mathrm{Mn}_{0.4} \mathrm{O}_{3-\delta}$ was identified as a promising catalyst for $\mathrm{EBDH}$ with steam under severe conditions.

\section{REFERENCES}

Adkin, J. J., and Hayward, M. A. (2006). Structure and magnetism of $4 \mathrm{H}$ $\mathrm{BaMnO}_{3-\mathrm{x}}(0 \leq \mathrm{x}<0.35)$ and $4 \mathrm{H}-$ $\mathrm{Ba}_{0.5} \mathrm{Sr}_{0.5} \mathrm{MnO}_{3-\mathrm{x}}(0 \leq \mathrm{x} \leq 0.21)$. J. Solid State Chem. 179, 70-76. doi: 10.1016/j.jssc.2005.09.046

Adkin, J. J., and Hayward, M. A. (2007). $\mathrm{BaMnO}_{3-x}$ revisited: a structural and magnetic study. Chem. Mater. 19, 755-762. doi: $10.1021 / \mathrm{cm} 062055 \mathrm{r}$

Carver, J. C., Schweitzer, G. K., and Carlson, T. A. (1972). Use of X-ray photoelectron spectroscopy to study bonding in $\mathrm{Cr}, \mathrm{Mn}, \mathrm{Fe}$, and Co compounds. J. Chem. Phys. 57, 973-982. doi: 10.1063/1.1678348

Cavani, F., and Trifirò, F. (1995). Alternative processes for the production of styrene. Appl. Catal. A 133, 219-239. doi: 10.1016/0926860X(95)00218-9

Chang, W. S., Chen, Y. Z., and Yang, B. L. (1995). Oxidative dehydrogenation of ethylbenzene over $\mathrm{V}^{I V}$ and $\mathrm{V}^{V}$ magnesium vanadates. Appl. Catal. A 124, 221-243. doi: 10.1016/0926-860X(94)00253-3

Cheng, Y., Zhao, H., Teng, D., Li, F., Lu, X., and Ding, W. (2008). Investigation of $\mathrm{Ba}$ fully occupied A-site $\quad \mathrm{BaCo}_{0.7} \mathrm{Fe}_{0.3-{ }_{\mathrm{x}}} \mathrm{Nb}_{\mathrm{x}} \mathrm{O}_{3-\delta}$ perovskite stabilized by low concentration of $\mathrm{Nb}$ for oxygen permeation membrane. J. Membr. Sci. 322, 484-490. doi: 10.1016/j.memsci.2008.05.065

Eggertsen, F. T., and Voge, H. H. (1947). Catalytic dehydrogenation. US Patent 2414585.

Ghaffari, M., Shannon, M., Hui, H., Tan, O. K., and Irannejad, A. (2012). Preparation, surface state and band structure studies of $\operatorname{SrTi}_{(1-x)} \mathrm{Fe}_{(\mathrm{x})} \mathrm{O}_{(3-\delta)}$ $(\mathrm{x}=0-1)$ perovskite-type nano structure by $\mathrm{X}$-ray and ultraviolet photoelectron spectroscopy. Surf. Sci. 606, 670-677. doi: 10.1016/j.susc.2011.12.013

Hirano, T. (1986). Dehydrogenation of ethylbenzene over potassiumpromoted iron oxide containing cerium and molybdenum oxides. Appl. Catal. 28, 119-132. doi: 10.1016/S0166-9834(00)82497-5

Kearby, K. K. (1945). Method for the catalytic dehydrogenation of hydrocarbons. US Patent 2370797.

Keller, N., Maksimova, N. I., Roddatis, V. V., Schur, M., Mestl, G., Butenko, Y. V., et al. (2002). The catalytic use of onion-like carbon materials for styrene synthesis by oxidative dehydrogenation of ethylbenzene. Angew. Chem. Int. Ed. 41, 1885-1888. doi: 10.1002/15213773(20020603)

Lee, E. H. (1974). Iron oxide catalysts for dehydrogenation of ethylbenzene in the presence of steam. Catal. Rev. Sci. Eng. 8, 285-305. doi: 10.1080/01614947408071864

Meima, G. R., and Menon, P. G. (2001). Catalyst deactivation phenomena in styrene production. Appl. Catal. A 212, 239-245. doi: 10.1016/S0926860X(00)00849-8

Miyakoshi, A., Ueno, A., and Ichikawa, M. (2001). Mn-substituted Fe$\mathrm{K}$ mixed oxide catalysts for dehydrogenation of ethylbenzene towards styrene. Appl. Catal. A 216, 137-146. doi: 10.1016/S0926-860X(01)00555-5

O’Hara, F. J. (1975). Dehydrogenation catalyst. US Patent 3904552.

Oku, M., and Hirokawa, K. (1976). $\mathrm{X}$-ray photoelectron spectroscopy of $\mathrm{Co}_{3} \mathrm{O}_{4}, \mathrm{Fe}_{3} \mathrm{O}_{4}, \mathrm{Mn}_{3} \mathrm{O}_{4}$, and related compounds. J. Elec. Spec. Rel. Phenom. 8, 475-481. doi: 10.1016/0368-2048(76)80034-5

Park, M. S., Vislovskiy, V. P., Chang, J. S., Shul, Y. G., Yoo, J. S., and Park, S. E. (2003). Catalytic dehydrogenation of ethylbenzene with carbon dioxide: promotional effect of antimony in supported vanadium-antimony oxide catalyst. Catal. Today 87, 205-212. doi: 10.1016/j.cattod.2003.10.015

Pitzer, E. W. (1958). Catalyst and dehydrogenation process. US Patent 2866791.

Ponce, S., Peña, M. A., and Fierro, J. L. G. (2000). Surface properties and catalytic performance in methane combustion of Sr-substituted lanthanum manganites. Appl. Catal. B 24, 193-205. doi: 10.1016/S09263373(99)00111-3

Reddy, B. M., Rao, K. N., Reddy, G. K., Khan, A., and Park, S. E. (2007). Structural characterization and oxidehydrogenation activity of $\mathrm{CeO}_{2} / \mathrm{Al}_{2} \mathrm{O}_{3}$ and $\mathrm{V}_{2} \mathrm{O}_{5} / \mathrm{CeO}_{2} / \mathrm{Al}_{2} \mathrm{O}_{3} \quad$ catalysts. J. Phys. Chem. C 111, 18751-18758. doi: 10.1021/jp0766171

Riesser, G. H. (1979). Dehydrogenation catalyst. US Patent 4144197.

Rokicki, A., Smith, D., and Williams, D. L. (2004). Dehydrogenation catalysts. US Patent 6756339.

Sakurai, Y., Suzaki, T., Nakagawa, K., Ikenaga, N., Aota, H., and Suzuki, T. (2000a). Oxidation capability of carbon dioxide in the dehydrogenation of ethylbenzene over vanadium oxide-loaded $\mathrm{MgO}$ catalyst. Chem. Lett. 29, 526-527. doi: $10.1246 / \mathrm{cl} .2000 .526$

Sakurai, Y., Suzaki, T., Ikenaga, N., and Suzuki, T. (2000b). Dehydrogenation of ethylbenzene with an activated carbonsupported vanadium catalyst. Appl. Catal. A 192, 281-288. doi: 10.1016/S0926-860X(99)00398-1

Sakurai, Y., Suzaki, T., Nakagawa, K., Ikenaga, N., Aota, H., and Suzuki, T. (2002). Dehydrogenation of ethylbenzene over vanadium oxide-loaded $\mathrm{MgO}$ catalyst: promoting effect of carbon dioxide. J. Catal. 209, 16-24. doi: 10.1006/jcat.2002.3593

Sekine, Y., Watanabe, R., Matsukata, M., and Kikuchi, E. (2008). High performance of $\mathrm{Fe}-\mathrm{K}$ oxide catalysts for dehydrogenation of ethylbenzene to styrene with an aid of ppmorder Pd. Catal. Lett. 125, 215-219. doi: 10.1007/s10562-008-9580-8

Shao, Z., Xiong, G., Tong, J., Dong, H., and Yang, W. (2001). Ba effect in doped $\mathrm{Sr}\left(\mathrm{Co}_{0.8} \mathrm{Fe}_{0.2}\right) \mathrm{O}_{3-\delta}$ on the phase structure and oxygen permeation properties of the dense ceramic membranes. Sep.
Purif. Technol. 25, 419-429. doi: 10.1016/S1383-5866(01)00071-5

Shiju, N. R., Anilkumar, M., Mirajkar, S. P., Gopinath, C. S., Rao, B. S. and Satyanarayana, C. V. (2005). Oxidative dehydrogenation of ethylbenzene over vanadia-alumina catalysts in the presence of nitrous oxide: structure-activity relationship. J. Catal. 230, 484-492. doi: 10.1016/j.jcat.2005.01.010

$\mathrm{Su}$, D., Maksimova, N. I., Mestl, G., Kuznetsov, V. L., Keller, V., Schlögl, R., et al. (2007). Oxidative dehydrogenation of ethylbenzene to styrene over ultra-dispersed diamond and onion-like carbon. Carbon 45, 2145-2151. doi: 10.1016/j.carbon.2007.07.005

Su, D., Zhang, J., Frank, B., Thomas, A., Wang, X., Paraknowitsch, et al. (2010). Metal-free heterogeneous catalysis for sustainable chemistry. ChemSusChem 3, 169-180. doi: 10.1002/cssc. 200900180

Su, D. S., Maksimova, N. I., Delgado, J. J., Keller, N., Mestl, G., Ledoux, M. J., et al. (2005). Nanocarbons in selective oxidative dehydrogenation reaction. Catal. Today 102-103, 110-114. doi: 10.1016/j.cattod.2005.02.012

Sugino, M., Shimada, H., Turuda, T., Miura, H., Ikenaga, N., and Suzuki, T. (1995). Oxidative dehydrogenation of ethylbenzene with carbon dioxide. Appl. Catal. A 121, 125-137. doi: 10.1016/0926860X(95)85015-5

Vente, J. F., Haije, W. G., and Rak, Z. S. (2006). Performance of functional perovskite membranes for oxygen production. J. Membr. Sci. 276, 178-184. doi. 10.1016/j.memsci.2005.09.046

Vislovskiy, V. P., Chang, J. S., Park, M. S., and Park, S. E. (2002). Ethylbenzene into styrene with carbon dioxide over modified vanadiaalumina catalysts. Catal. Commun. 3, 227-231. doi: 10.1016/S15667367(02)00105-X

Wang, H., Tablet, C., Feldhoff, A., and Caro, J. (2005). Investigation 
of phase structure, sintering, and permeability of perovskite-type $\mathrm{Ba}_{0.5} \mathrm{Sr}_{0.5} \mathrm{Co}_{0.8} \mathrm{Fe}_{0.2} \mathrm{O}_{3-\delta} \quad$ membranes. J. Membr. Sci. 262, 20-26. doi: 10.1016/j.memsci.2005.03.046

Watanabe, R., Mukawa, K., Kojima, J., Kikuchi, E., and Sekine, Y. (2013). Dehydrogenation of ethylbenzene over $\quad \mathrm{La}_{0.8} \mathrm{Ba}_{0.2} \mathrm{Fe}_{0.4} \mathrm{Mn}_{0.6} \mathrm{O}_{3-\delta}$ perovskite oxide catalyst working by redox mechanism using steam and lattice oxygen. Appl. Catal. A 462-463, 168-177. doi: 10.1016/j.apcata.2013.04.041

Watanabe, R., Sekine, Y., Kojima, J., Matsukata, M., and Kikuchi, E. (2011). Dehydrogenation of ethylbenzene over highly active and stable perovskite oxide catalyst - Effect of lattice oxygen on/in perovskite oxide and role of $\mathrm{A} / \mathrm{B}$ site in perovskite oxide. Appl. Catal. A 398, 66-72. doi: 10.1016/j.apcata.2011.03.016
Watanabe, R., Sekine, Y., Matsukata, M., and Kikuchi, E. (2009). Novel perovskite-type oxide catalysts for dehydrogenation of ethylbenzene to styrene. Catal. Lett. 131, 54-58. doi: 10.1007/s10562-009-0028-6

Won, J. K., and Jang, H. H. (2011) Method for improving productivity and process stability in styrene manufacturing system having multiple reactors connected in series. US Patent 2011/0166399.

Xu, J., Wang, L. C., Liu, Y. M., Cao Y., He, H. Y., and Fan, K. N. (2009). Mesostructured $\mathrm{CeO}_{2}$ as an effective catalyst for styrene synthesis by oxidative dehydrogenation of ethylbenzene. Catal. Lett. 133, 307-313. doi: 10.1007/s10562-0090174-x

Zeng, P., Chen, Z., Zhou, W., Gu, H., Shao, Z., and Liu, S. (2007). Re-evaluation of $\mathrm{Ba}_{0.5} \mathrm{Sr}_{0.5} \mathrm{Co}_{0.8} \mathrm{Fe}_{0.2} \mathrm{O}_{3}-\delta$ perovskite as oxygen semi-permeable membrane. J. Membr. Sci. 291, 148-156. doi: 10.1016/j.memsci.2007.01.003

Zhao, T. J., Sun, W. Z., Gu, X. Y. Rønning, M., Chen, D., Dai, Y. C., et al. (2007). Rational design of the carbon nanofiber catalysts for oxidative dehydrogenation of ethylbenzene. Appl. Catal. A 323, 135-146. doi: 10.1016/j.apcata.2007.02.008

Conflict of Interest Statement: The authors declare that the research was conducted in the absence of any commercial or financial relationships that could be construed as a potential conflict of interest.

Received: 27 July 2013; paper pending published: 05 September 2013; accepted: 24 September 2013; published online: 23 October 2013.
Citation: Watanabe $R$, Ikushima $M$ Mukawa K, Sumomozawa F, Ogo S and Sekine $Y$ (2013) Lanthanoid-free perovskite oxide catalyst for dehydrogenation of ethylbenzene working with redox mechanism. Front. Chem. 1:21. doi: 10.3389/fchem.2013.00021

This article was submitted to Green and Environmental Chemistry, a section of the journal Frontiers in Chemistry. Copyright (c) 2013 Watanabe, Ikushima, Mukawa, Sumomozawa, Ogo and Sekine. This is an open-access article distributed under the terms of the Creative Commons Attribution License (CC BY). The use, distribution or reproduction in other forums is permitted, provided the original author(s) or licensor are credited and that the original publication in this journal is cited, in accordance with accepted academic practice. No use, distribution or reproduction is permitted which does not comply with these terms. 